\title{
Scleractinian corals with photoprotective host pigments are hypersensitive to thermal bleaching
}

\author{
Sophie Dove* \\ Centre for Marine Studies, University of Queensland, St Lucia, Queensland, 4072, Australia
}

\begin{abstract}
Recent episodes of mass coral bleaching, the loss of symbiotic dinoflagellates or photosynthetic pigment from hermatypic corals, have been triggered by elevated sea temperatures. Photosynthetic irradiance is an important secondary factor. Host based pigments (pocilloporins or Green Fluorescent Protein homologues) have been proposed to reduce the impact of elevated temperature by shading the dinoflagellate symbionts of corals, thereby reducing light stress. This study investigates this phenomenon in the reef-building coral Acropora aspera from Heron Island Research Station (Great Barrier Reef, Australia), which occurs as 3 distinct colour morphs. Experimental data showed that the host pigments are photoprotective at normal temperatures or $<32^{\circ} \mathrm{C}_{\text {; }}$ however, the loss of symbionts and reduction in the quantum yield of photosynthesis (dark adapted $F_{\mathrm{v}} / F_{\mathrm{m}}$ ) observed after exposure to elevated temperature was most severe in the heavily pigmented blue morph, eventually resulting in death of most experimental colonies. The results suggest that the protection offered by pocilloporins and other GFP-homologues is reduced by thermal stress, potentially leaving the shade-acclimated symbionts of heavily pigmented corals exposed to high light levels. Mature host pigments are thermally stable, but they are potentially vulnerable to heat during mRNA and protein synthesis and/or maturation. It is clear, however, that the broad assumption that host pigmented corals are less vulnerable to thermal stress is incorrect.
\end{abstract}

KEY WORDS: Host pigments · GFP · Photoinhibition · Bleaching $\cdot$ Scleractinian corals

\section{INTRODUCTION}

The vivid colours of symbiotic corals are predominantly due to host pigments that have been identified as homologues to Green Fluorescent Protein (GFP). GFPs are all protein chromophores, the first of which was isolated from the hydrozoan jelly-fish Aequorea victoria (Yang et al. 1996). Many of these homologues fluoresce with colours other than green. Some have quantum yields close to zero and exhibit little or no fluorescence (Dove et al. 1995, Matz et al. 1999, Dove et al. 2001a, Gurskaya et al. 2001, Labas et al. 2002). This family of proteins probably accounts for a significant proportion of the host colours identified across all classes of cnidarians (Dove et al. 1995, Matz et al. 1999, Dove et al. 2001a, Gurskaya et al. 2001, Labas et al. 2002), including scleractinian corals (Dove et al. 2001a, Gurskaya et al. 2001, Labas et al. 2002). The function of these proteins in corals has been a matter of speculation since the pioneer work of Kawaguti (1944). The weight of evidence suggests that they play some sort of photoprotective role against photosynthetic or ultraviolet radiation, either for host tissue or for their symbiotic algae (Salih et al. 2000, Dove et al. 2001a). Arguing against this proposed role, however are the observations that (1) different pigmented varieties of the same species exist side by side in the field (Takabayashi \& Hoegh-Guldberg 1995, Salih et al. 2000); (2) there appears to be no clear correlation between pigment concentrations and depth (Takabayashi \& Hoegh-Guldberg 1995, Mazel et al. 2003); (3) pigmentation in coral colonies is frequently limited to growing regions where the density of symbiotic dinoflagellates is at its lowest (Takabayashi \& Hoegh-Guldberg 1995); and (4) the fluorescent strength of host pigments does not correlate with the removal of photons from chlorophyll excitation (Mazel et al. 2003). 
There is growing concern about the increased frequency of bleaching events occurring in coral reef ecosystems. Bleaching (the loss of endosymbiotic microalgae and/or their pigments) results in a loss of the brown colour associated with the symbionts of scleractinian corals (Hoegh-Guldberg 1999). It is a response to a variety of environmental stresses (Brown \& Howard 1985). On the global scale (mass coral bleaching) however, it is predominantly triggered by increases in sea temperature above long-term summer maxima of as little as $1^{\circ} \mathrm{C}$ (Hoegh-Guldberg 1999). The underlying cause for thermal bleaching is thought to involve the impairment of algal symbiont photosynthesis (Jones et al. 1998) due to thermal damage to the dark reactions of photosynthesis or thermal inactivation of the water splitting complex of Photosystem II (PSII; Iglesias-Prieto 1997). This impairment results in captured photic energy overwhelming the photoprotective mechanisms of the symbiont, and leads to an increased sensitivity to photodamage (e.g. photoinhibition model of thermal bleaching, Jones et al. 1998). This model predicts that conditions that lead to an increased energy input into the symbionts' photosystems will hasten the detrimental effects of temperature (Schreiber et al. 1995, HoeghGuldberg 1999). The model has led to the further prediction: Host pigments, by providing shade and dampening fluctuations in irradiance, will provide greater protection against the effects of bleaching in response to elevated temperatures (Hoegh-Guldberg 1999, Salih et al. 2000).

Acropora aspera is a branching coral that is abundant in high irradiance habitats on the reef flat of Heron Island and the Australian Great Barrier Reef in general. It occurs as 3 basic colour varieties: (1) blue throughout most of the branch; (2) light blue at the tip only, brown elsewhere and (3) creamy-brown throughout. The different colour morphs occur adjacently and belong to a single species, based on morphological (Veron 2000) and molecular (van Oppen et al. 2001a) characteristics. Select branches of the cream morph occasionally turn a reversible pink colour, and similarly select branches of the light blue morph occasionally turn fluorescent green. Despite these rare shifts in colour, colour interchange between morphs (e.g. cream shifting to blue or vice-versa) has not been observed. This lack of interchange between dominant colour morphs agrees with similar observations for other species (e.g. Takabayashi and Hoegh-Guldberg 1995) and indicates that they are probably genotypes within the species $A$. aspera. Studies of the molecular or cladal classification of $A$. aspera symbionts suggest that they belong to a single subclade (C2; van Oppen et al. 2001b).

Physiological differences in photoadaptive abilities have been observed amongst cultured dinoflagellates isolated from distinct organisms (Iglesias-Prieto \& Trench 1997) that have subsequently been typed into distinct subclades (LaJeunesse 2001). Direct correlation between physiological responses and cladal identity have also demonstrated that only cultured clade type A symbionts (from high-light specializing corals collected in the Caribbean; Rowan et al. 1997) produced significant quantities of the UV absorbing mycosporine-like amino acids (MAAs) under experimental conditions (Banaszak et al. 2000). Studies of the physiological responses of symbionts per se to light are currently based on cultured or freshly isolated dinoflagellates because it is not possible to eliminate the confounding effect of host tissue on symbiont response in hospite. For example, Fitt \& Cook (2001) compared photosynthesis-irradiance (P-I) curves of freshly isolated dinoflagellates to those of intact associations and found that, in the host cell, the light environment was halved. They argued 'this phenomenon may protect the algae from photobleaching of pigments and/or photoinhibition of photosynthesis at high light intensities'. In the case of Acropora aspera, symbionts in different host colour morphs may be in different states (e.g. have different xanthophyll pool sizes; Brown et al. 1999), but this is likely to be driven by the differential ability of the host cells to filter the light that impacts on the endosymbiont. The validity of this presumption is of course dependant on how well the van Oppen et al. (2001b) symbiont typing stands up to examination. It is the apparent simplicity of the $A$. aspera symbiosis that makes it attractive for investigations into the photoprotective role of host pigment proteins. The specific question of this study is whether the additional photoprotection offered by these pigments can lead to a greater resistance to coral bleaching (Salih et al. 2000), much in the same way as the shaded regions of corals are more resistant to thermal bleaching than their light exposed regions (Jones et al. 1998).

\section{MATERIALS AND METHODS}

Spectral properties of 3 colour morphs of Acropora aspera. Branches were randomly selected from 10 individuals each of blue, cream, green and light blue morphs of $A$. aspera growing on the reef flat of Heron Island. Branches were immersed in $3 \mathrm{ml}$ of phosphate buffer $\mathrm{pH} 6.65$ and left at $4^{\circ} \mathrm{C}$ for $72 \mathrm{~h}$. They were then removed from solution (raw extract), dipped briefly in dilute bleach and left to dry in preparation for measuring their surface areas using paraffin-wax technique (Stimson \& Kinzie 1991). Raw extracts were filtered through $0.45 \mu \mathrm{m}$ syringe filters (Millipore) and absorption spectra were determined using a UVPC 2450 (Shimatzu) with a $1 \mathrm{~nm}$ silt width. Five random samples 
$(200 \mu l)$ of each colour morph were analysed by gel filtration chromatography on a Superose FPLC column (Pharmacia, 12 HR 10/30). Chromatograms were monitored at $235 \mathrm{~nm}$ and $280 \mathrm{~nm}$ using a multi-wavelength detector (Model 490E; Millipore-Waters), and protein chromatograms calculated using the method of Whitaker \& Granum (1980) were normalised to surface area.

Experimental design. Twenty-four branches were collected from each of 6 colonies each of the blue, light blue and cream colour morphs of Acropora aspera. Green branches were too rare to be used experimentally. Only branches that were approximately perpendicular to the sea surface were chosen. Colonies were collected from an area of the Heron Island reef flat that was no greater than $400 \mathrm{~m}^{2}$, of uniform depth with a tidal range of 0.1 to $3 \mathrm{~m}$, and had a midday light intensity range of 300 to $2200 \mu \mathrm{mol}$ quanta $\mathrm{m}^{-2} \mathrm{~s}^{-1}$ over the summer months. Branches were placed vertically in PVC tubing, resulting in 24 racks per colour morph each containing 6 branches (one from each colony). Racks were placed in a partially shaded recovery tank for $10 \mathrm{~d}$. At sunset, $10 \mathrm{~d}$ after collection, the racks were moved into experimental tanks with 4 racks from each colour morph being moved into a total of 6 tanks.

The experimental light and temperature conditions were designed to mirror conditions that may be expected to give rise to a bleaching event for corals in their specific habitats. It was not possible to replicate experimentally the $3 \mathrm{~m}$ tidal regimes that corals experience on Heron Island reef flat. Tanks were located in an open area of Heron Island Research Station. Due to shading by trees and buildings, corals placed in the aquaria were subject to direct sunlight between 10:00 $\mathrm{h}$ and 15:00 $\mathrm{h}$. Due to linear positioning and the movement of the sun from east to west, Tank Set 1 (hot and ambient) experienced slightly more direct morning sun than Tank Sets 2 and 3, and Tank Set 3 experienced slightly more direct afternoon sun. Corals were also subjected to elevated temperatures above an ambient background instead of flat-lined at a set temperature, and temperatures were gradually increased over a number of days (see Fig. 4A).

The experimental tanks consisted of a flow-through system with 3 paired tanks set up such that one of the pairs was heated above the other by a controlled amount $\left(0\right.$ to $\left.4 \pm 0.5^{\circ} \mathrm{C}\right)$. The temperature regime in the 3 heated tanks was as described in Figs. 4A \& 5A. The temperature was increased to $2^{\circ} \mathrm{C}$ above ambient at 10:00 $\mathrm{h}$ on Day $2,3^{\circ} \mathrm{C}$ above ambient at $10: 00 \mathrm{~h}$ on Day $3,4^{\circ} \mathrm{C}$ above ambient at $10: 00 \mathrm{~h}$ on Day 4 and maintained at this temperature until 21:00 $\mathrm{h}$ on Day 7.

A light logger was mounted $2 \mathrm{~m}$ above the experimental tanks. The tips of the corals were located $0.3 \mathrm{~m}$ below the water surface and, hence, irradiance at the surface of the coral explants was attenuated by this column of water. Light data were recalculated using a clean water attenuation coefficient $\left(0.3 \mathrm{~m}^{-1}\right.$; Jerlov 1976) to give a rough estimation of daily irradiance experienced by the corals throughout the course of the experiment (see Fig. 4A). After 7 d, corals were moved to an unheated tank that offered $50 \%$ shade and left to recover for a further $41 \mathrm{~d}$.

Measurement of the effective quantum yield of photochemical energy conversion. The effective quantum yield of photosystem II of the resident symbiotic dinoflagellates was determined by pulse-amplitude modulated (PAM) fluorometry using a DIVINGPAM Underwater Fluorometer (Walz) fitted with a red-LED $(650 \mathrm{~nm})$ measuring light. Measurements were taken from the same oriented vertical plane on each branch, approximately $2 \mathrm{~cm}$ below the tip, starting at $2 \mathrm{~h}$ after sunset $(20: 00 \mathrm{~h})$ on Days 1 to $8,10,12$ and 48 of the experiment. The initial fluorescence $\left(F_{0}\right)$ was measured using $3 \mu$ s pulses of the measuring light. A saturating pulse of white light $(8000 \mu \mathrm{mol}$ quanta $\mathrm{m}^{-2} \mathrm{~s}^{-1}$ photosynthetically active radiation [PAR]) was then applied to give a maximal fluorescence value $\left(F_{\mathrm{m}}\right)$. The ratio of variable fluorescence $\left(F_{\mathrm{v}}\right.$, where $\left.F_{\mathrm{v}}=F_{\mathrm{m}}-F_{\mathrm{o}}\right)$ to $F_{\mathrm{m}}$ in a dark-adapted sample is a good proxy for the potential quantum yield of photochemical energy conversion (Schreiber et al. 1995).

Algal counts, DNA isolation and total animal soluble protein estimation. One rack of each colour morph was removed from each of the 6 tanks at the end of Days 2, 5, 7 and 48. Branches were stored in individual plastic bags and frozen at $-20^{\circ} \mathrm{C}$. Prior to analysis, branches were cut to obtain segments (1 to $3 \mathrm{~cm}$ from tip) that corresponded approximately to the area investigated by PAM fluorometry. The tissue was removed with a jet of recirculating $0.45 \mu \mathrm{m}$ filtered seawater from a $50 \mathrm{ml}$ reservoir and the homogenate was centrifuged at $5000 \times g$ for $5 \mathrm{~min}$. The supernatant was diluted 1:4 with seawater for determination of total animal protein by the method of Whitaker \& Granum (1980), calibrated to an IgG standard. Algal pellets were resuspended in $5 \mathrm{ml}$ of filtered seawater, vortexed and aliquoted into three $1.5 \mathrm{ml}$ vials to be used for algal counting, DNA isolation and storage at $-20^{\circ} \mathrm{C}$ respectively. Counting consisted of 8 replicate hemacytometer counts and data were expressed per unit surface area as determined by the paraffin-wax technique (Stimson \& Kinzie 1991).

Genetic characterisation. Four adjacent calices were removed with a razor blade from approximately $2 \mathrm{~cm}$ below branch tips and DNA was isolated with the DNeasy tissue kit (Qiagen). This provided regionally specific DNA from both host and symbiont. 
Isolation of the D1 and D2 regions of the large subunit (LSU) of algal rDNA was achieved using primers lsu-UFP1 and lsu-URP1 (Zardoya et al. 1995) and the following PCR amplification protocol: 1 cycle of $5 \mathrm{~min}$ at $95^{\circ} \mathrm{C} ; 35$ cycles of $1 \mathrm{~min}$ at $94^{\circ} \mathrm{C}, 1 \mathrm{~min}$ at $55^{\circ} \mathrm{C}, 1 \mathrm{~min}$ at $72^{\circ} \mathrm{C}$; followed by $8 \mathrm{~min}$ at $72^{\circ} \mathrm{C}$. Isolation of the algal ITS regions and 5.8S RNA gene was achieved as described by Coleman et al. (1994) using their $\mathrm{a}$ and $\mathrm{b}$ primers.

Sequencing of PCR amplified regions. PCR products were electrophoresed on $1 \%$ agarose gel, appropriate bands purified with the GFX purification kit (Amersham) and cloned into pGemT-Easy (Promega) for ABI sequencing by the Australian Genome Research Facility (AGRF, University of Queensland). Four clones were sequenced by PCR reactions in both forward and reverse directions, and sequences were aligned using EclustAlW (ANGIS) and BLASTN against the NRdatabase (NCBI).

Field data collections. Samples were collected randomly from 5 marked colonies of each colour morph $(\mathrm{n}=5)$ pre-bleaching (morning, 6 and 8 January 2002) and during the bleaching event (afternoon, 8 March 2002). They were immediately frozen at $-20^{\circ} \mathrm{C}$, and used for algal density and total animal soluble protein estimations as described for the experimental coral explants.

Light and temperature measurements. Light was measured at 400 to $700 \mathrm{~nm}$ with a DATAFLOW SYSTEM cosine-corrected photosynthetic irradiance sensor. Temperature was record with a DATAFLOW temperature recording system with a resolution of $0.02^{\circ} \mathrm{C}$. Both systems were deployed vertically. Temperature calibrations were achieved in a water bath (Haake). Light sensors were calibrated both in air and in water, against a LI-COR quantum sensor (Li-Cor Biosciences) at an interval of $5 \mathrm{~min}$. Light sensors deployed in the field collected data at an interval of $20 \mathrm{~min}$, and a further correction factor was included in the calibration to correct for the effect of cumulating data over different intervals. Light measurements taken in air were also adjusted to the water depth of immersed coral by an attenuation coefficient of $0.3 \mathrm{~m}^{-1}$ (Jerlov 1976).

Statistical analysis. Factorial multivariate and univariate analyses of variance using sigma parameterisation were performed on the data. Day (for experimental), Time (for field), Temp (temperature), Light and Tank (tank set) were analysed as within-subject factors because they were repeated measures on the same colony or individual. The among-subject factor, Colour had 3 levels corresponding to the 3 morphs, with 6 replicate colonies for each level. Cochran's $C$, Bartlett's Chi-squared and Hartley's $F$-max tests were used to examine the assumption of homogeneity of variance. Multivariate analyses of variance (MA-
NOVA) are offered in addition to univariate analyses to demonstrate that any rejections of $\mathrm{H}_{\mathrm{o}}$ were not based on an inflated rate of Type I error resulting from breaks to the assumption of sphericity (Zar 1999). The 4 common MANOVA statistical tests (Wilk's, Pillai's, Hotelling's and Roy's) were found to be in agreement and hence only the results from Wilk's are shown. Significance levels of $\mathrm{p}<0.01$ were adopted when homogeneity could not be acheived through log-transformation (Underwood 1997). Where MANOVA and ANOVA determined a significant difference, StudentNewman-Keuls (SNK) tests were applied to attribute differences between specific treatments and levels.

\section{RESULTS}

\section{Spectral properties of 3 colour morphs of Acropora aspera}

Absorbance spectrums of raw phosphate buffer extracts from blue, light blue, green and cream colour morphs of Acropora aspera collected from adjacent positions on the reef flat of Heron Island showed that the blue morph absorbed significantly ( $\alpha=0.05, \mathrm{~N}=10$ ) more visible light energy inclusive of UVA (360 to $660 \mathrm{~nm}$ ), but not more UVB, than the cream or the light blue morphs (Fig. 1A). The dominant blue coloration was due to pigments previously identified as pocilloporins (Dove et al. 1995), a family of water-soluble allprotein chromophores that are related to the Green Fluorescent Proteins (GFP, Dove et al. 20001a) and which elute after approximately $50 \mathrm{ml}$ of phosphate buffer have passed through the gel filtration column (GFPhomologues Fig. 1B, Dove et al. 1995, Dove et al. 2001a). The concentration of total GFP-like protein normalised to surface area was greatest in the blue morph (ca. $1.1 \mathrm{mg} \mathrm{cm}^{-2}$ ) and least in the light blue and green morphs (ca $0.5 \mathrm{mg} \mathrm{cm}^{-2}$, Fig. 1B) with the cream morph having an intermediate value (ca. $0.8 \mathrm{mg} \mathrm{cm}^{-2}$, Fig. 1B). Branches (ca. $3 \mathrm{~cm}$ long) of $A$. aspera collected from the reef flat of Heron Island at low tide contained blue pocilloporin in the range of 0.4 to $0.8 \mathrm{mg} \mathrm{cm}^{-2}$ (extinction coefficient from S. Dove et al. unpubl., Fig. 1A,B).

\section{Do the different colour morphs of Acropora aspera host a single algal subclade?}

Alignment of the large subunit ribosomal RNA gene domains D1 and D2 from all colour morphs of Acropora aspera $^{1}$ showed greater identity with the full length subclade C2 sequences, than with either subclades C1 or C3 isolated by van Oppen et al. (2001b). The small subunit ribosomal RNA gene ${ }^{2}$ together with the ITS1 
and ITS2 flanking regions, obtained from PCR amplification with the a and $b$ primers of Coleman et al. (1994), aligned with C2 (NCBI-van Oppen, ITS1) and C3 (NCBI-LaJeunesse, ITS2). This was an artefact derived from inconsistent nomenclature and not suggestive of different subclades.

\section{Photoprotective properties of the 3 colour morphs of Acropora aspera}

Analysis of the photosynthetic efficiency of the symbiotic dinoflagellates in light (ca. $1270 \mu \mathrm{mol}$ quanta $\mathrm{m}^{-2}$ $\mathrm{s}^{-1}$ ) and shade (ca. $730 \mu \mathrm{mol}$ quanta $\mathrm{m}^{-2} \mathrm{~s}^{-1}$ ) exposed corals by pulse-amplitude modulated (PAM) fluorometry suggested that the algal symbionts in the heavily pigmented blue morph are less susceptible to changes in irradiance than the less pigmented light blue and cream morphs. Repeated measure ANOVAs with among-subject factor 'Colour' and within-subject factor 'Light' were set up to test the null hypothesis that differences in symbiont densities and photosynthetic efficiencies resulting from changes in light intensity are independent of colour morph. Significant interactions between Light and Colour were observed for symbiont density data ( $\mathrm{p}<0.0002$, Table $1 \mathrm{~A})$, and for dark-adapted $F_{\mathrm{v}} / F_{\mathrm{m}}$ data $(\mathrm{p}<0.0000$, Table $1 \mathrm{~B})$ suggesting that the null hypothesis should be rejected. Post hoc analyses (SNK) identified that the blue morph was less sensitive to this changing light environment than the cream or light blue morphs (Table 1, Fig. 2).

Repeated measure univariate and multivariate analyses of variance with among-subject factor 'Colour'
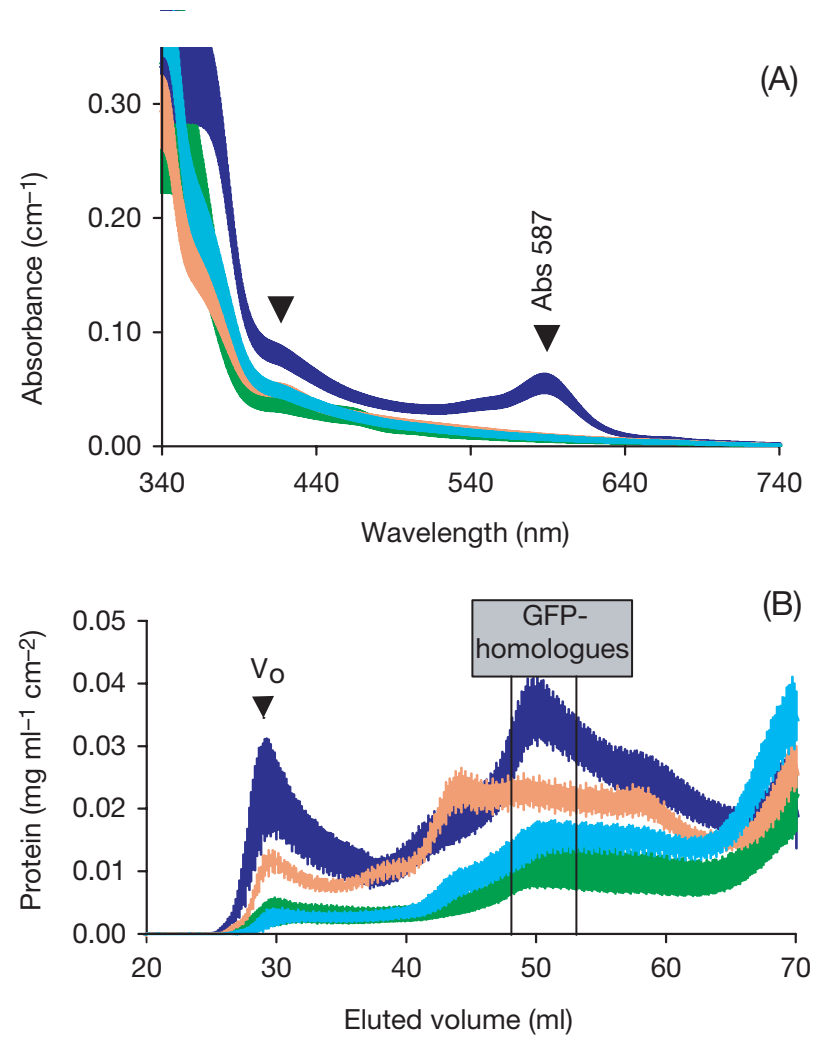

Fig. 1. Acropora aspera. (A) Absorption spectra for blue (๑), cream (○), green (O) and light blue $(\bigcirc)$ branches in $3 \mathrm{ml}$ of phosphate buffer normalised to surface area. Shown are $95 \%$ confidence intervals for $\mathrm{n}=10$ colonies. (B) Chromatogram of protein $\left(\mathrm{mg} \mathrm{ml}^{-1}\right)$ per surface area of coral $\left(\mathrm{cm}^{2}\right)$ eluting through a superose HR12 Gel filtration column for blue (๑), cream (○), green (๑), and light blue (๑) morphs. Shown are $95 \%$ confidence intervals for $\mathrm{n}=5$ colonies. $\mathrm{V}_{0}=$ void volume Arrows indicate $\lambda_{\max }$ for known GFP-homologues

Table 1. Acropora aspera. Repeated measure ANOVAs using sigma parameterization, testing the hypotheses that differences in (A) symbiont densities and (B) photosynthetic efficiencies resulting from a change in light intensity are independent of colour morph. Colour (B, blue; $\mathrm{C}$, cream; LB, light blue morphs; among-subject factor), Light (2 intensities, within-subject factor)

\begin{tabular}{|c|c|c|c|c|c|c|}
\hline Source of variation & SS & $\mathrm{df}$ & MS & $F$ & $\mathrm{p}$ & SNK (0.05) \\
\hline \multicolumn{7}{|l|}{ (A) Symbiont $\mathbf{c m}^{-2}$} \\
\hline Colour & $1.24 \mathrm{E}+12$ & 2 & $6.20 \mathrm{E}+11$ & 6.29 & 0.0104 & $\mathrm{~B}>0.008 \mathrm{C}$ \\
\hline $\mathrm{S} /$ Colour $^{\mathrm{a}}$ & $1.48 \mathrm{E}+12$ & 15 & $9.86 \mathrm{E}+10$ & & & \\
\hline Light & $2.15 E+13$ & 1 & $2.15 E+13$ & 221.04 & 0.0000 & Shade $>_{0.0002}$ Light \\
\hline Light $\times$ Colour & $3.07 \mathrm{E}+12$ & 2 & $1.54 \mathrm{E}+12$ & 15.80 & 0.0002 & $\begin{array}{l}\mathrm{B}_{\text {(shade) }}>0.001 \mathrm{~B}_{\text {(light); }} \mathrm{C}_{\text {(shade) }}>0.0002 \mathrm{C}_{\text {(light) }} \\
\mathrm{LB}_{\text {(shade) }}\end{array}$ \\
\hline Light $\times$ S/Colour & $1.46 \mathrm{E}+12$ & 15 & $9.72 \mathrm{E}+10$ & & & $\begin{array}{l}\mathrm{B}_{\text {(light) }}>_{0.0004} \mathrm{C}_{\text {(light) }}=0.65 \mathrm{LB}_{\text {(light) }} \\
\mathrm{B}_{\text {(shade) }}={ }_{0.76} \mathrm{C}_{\text {(shade) }}<_{0.026} \mathrm{LB}_{\text {(shade) }}\end{array}$ \\
\hline \multicolumn{7}{|c|}{ (B) Dark adapted $F_{\mathrm{v}} / F_{\mathrm{m}}$} \\
\hline Colour & 0.0043 & 2 & 0.0022 & 14.56 & 0.0003 & $\mathrm{~B}>_{0.023} \mathrm{C}>_{0.012} \mathrm{LB}$ \\
\hline S/Colour & 0.0022 & 15 & 0.0001 & & & \\
\hline Light & 0.0288 & 1 & 0.0288 & 123.63 & 0.0000 & Shade $>_{0.0002}$ Light \\
\hline Light $\times$ Colour & 0.0102 & 2 & 0.0051 & 22.01 & 0.0000 & $\begin{array}{l}\mathrm{B}_{\text {(shade) }}={ }_{0.2} \mathrm{~B}_{\text {(light) }} ; \mathrm{C}_{\text {(shade) }}>_{0.0002} \mathrm{C}_{\text {(light) }} ; \\
\mathrm{LB}_{\text {(shade) }}>>_{0.0002} \mathrm{LB}_{\text {(light) }}\end{array}$ \\
\hline Light $\times$ S/Colour & 0.0035 & 15 & 0.0002 & & & $\begin{array}{c}\mathrm{B}_{\text {(light) }}>_{0.0003} \mathrm{C}_{\text {(light) }}>_{0.0006} \mathrm{LB}_{\text {(light) }} \\
\mathrm{B}_{\text {(shade) }}={ }_{0.13} \mathrm{C}_{\text {(shade) }}=0.68 \mathrm{LB}_{\text {(shade) }}\end{array}$ \\
\hline
\end{tabular}



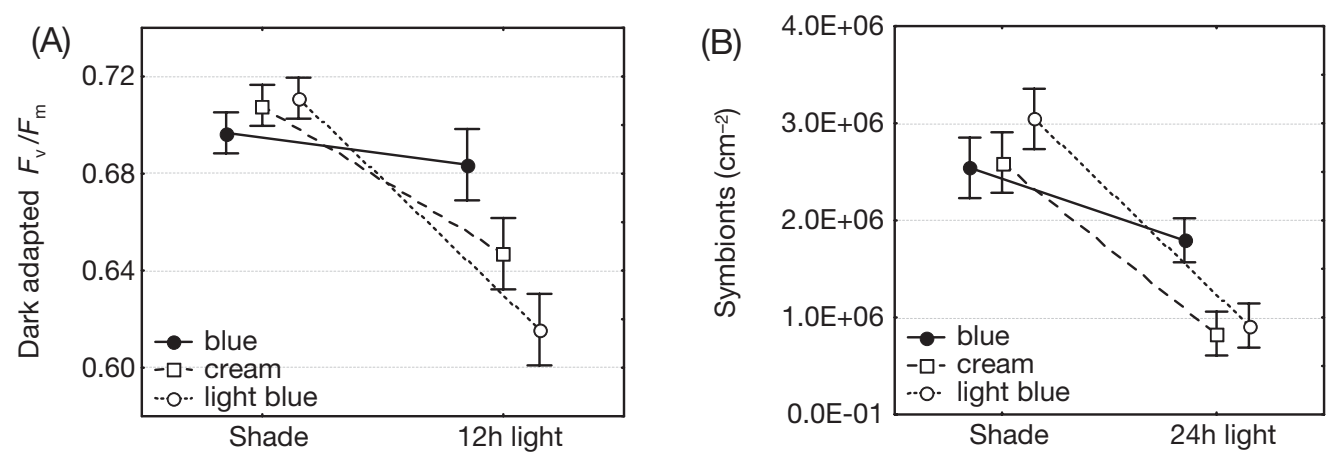

Fig. 2. Acropora aspera. (A) Photosynthetic efficiency measured as dark adapted $F_{\mathrm{v}} / F_{\mathrm{m}}$ by a diving PAM fluorometer, approximately $2 \mathrm{~cm}$ from the tip. $12 \mathrm{~h}$ light: unheated corals moved from semi-shade to a high-light environment and left for $12 \mathrm{~h}$; shade: unheated corals left in the shade for $5 \mathrm{~d}$. (B) Algal densities per surface area of a $2 \mathrm{~cm}$ cylinder. $24 \mathrm{~h}$ light: unheated corals moved from semi-shade to a high-light environment and left for $24 \mathrm{~h}$; shade: unheated corals left in the shade for $32 \mathrm{~d}$. Data shown correspond to the graphical output for repeated measures ANOVAs on 6 colonies of each of the morphs. Error bars represent $95 \%$ confidence intervals. Data is offset on the $x$-axis for clarity

and within-subject factors 'Day' and 'Tank' were setup to test the null hypothesis that differences in symbiont densities and photosynthetic efficiencies for controls in the days following a change in light intensity are independent of colour morph. Significant interactions between Day and Colour were observed for symbiont density data ( $\mathrm{p}<0.0008$, Table $2 \mathrm{~B}$ ), and for darkadapted $F_{\mathrm{v}} / F_{\mathrm{m}}$ data $(\mathrm{p}<0.0012$, Table 3B) suggesting that the null hypothesis should be rejected. Multivari-
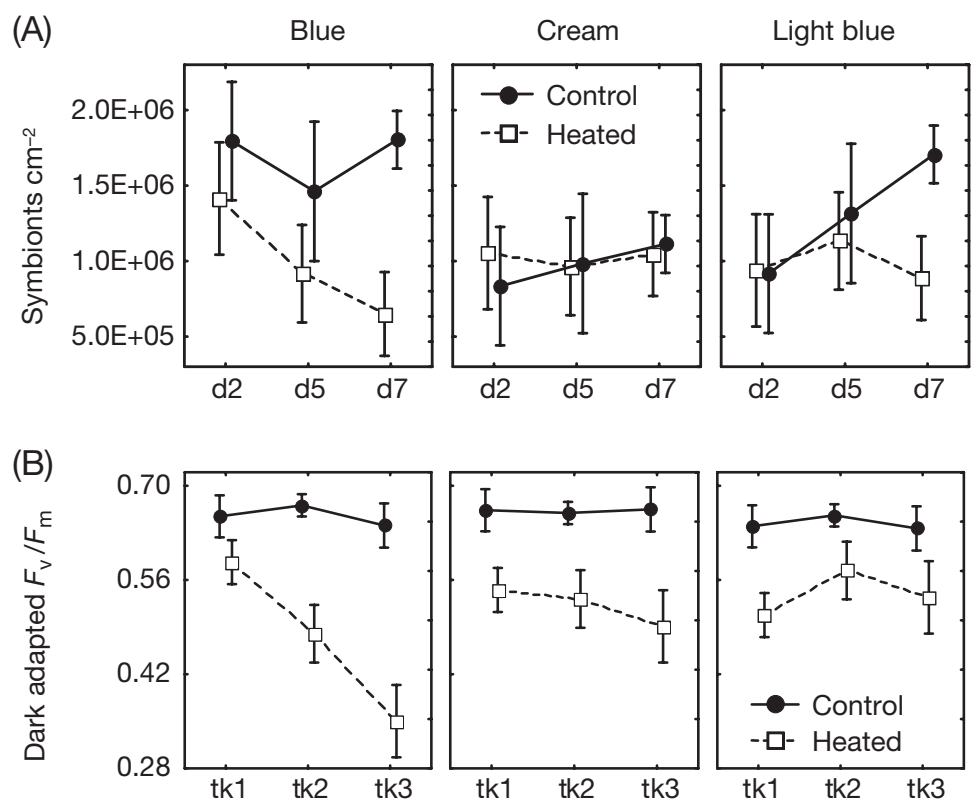

Fig. 3. Acropora aspera. (A) Symbiotic algal densities per surface area of a $2 \mathrm{~cm}$ cylinder during the high light experimental interval $\left(\mathrm{d} 2,+2^{\circ} \mathrm{C}\right.$; d5 $\left.-\mathrm{d} 7,+4^{\circ} \mathrm{C}\right) ;\left(\right.$ B) Day 7 , dark adapted $F_{\mathrm{v}} / F_{\mathrm{m}}$ for Tank Sets (tk) 1 to 3 . Error bars represent $95 \%$ confidence intervals. Data is offset on the $x$-axis for clarity ate analysis also suggested a rejection of the null hypothesis ( $p<0.0052, p<0.0054$ respectively, Tables $2 \mathrm{~A} \& 3 \mathrm{~A})$. Post hoc analyses identified that only the light blue morph showed a significant change in symbiont densities through this time frame (Table 2B, Fig. 3A, controls only). Over $5 \mathrm{~d}$ under high light, dinoflagellates in the light blue morph increased their population by a minimum of $15 \%$, recovering to the symbiont densities observed in the blue explants (Fig. 3A, controls only). This corresponds to a $3 \% \mathrm{~d}^{-1}$ increase that is well within the range observed by Jones \& Yellowlees (1997) for naturally growing symbiont populations. No such recovery was observed for the cream explants (Fig. 3A, controls only).

A significant interaction between Day, Tank and Colour was also observed for symbiont densities (univariate, $\mathrm{p}<0.0146$, Table 2B; multivariate, $\mathrm{p}<0.0193$, Table 2A). Again, post hoc analysis identified the light blue morph as being significantly variable in symbiont densities between days and tanks (Table 2B).

\section{Comparison between experimental and field bleaching conditions}

A mass-bleaching event affected most of the Great Barrier Reef between January and March 2002 (Denis 2002). Corals growing on Heron Island reef flat between the end of January and the beginning of March 2002 experienced temperatures in excess of $32^{\circ} \mathrm{C}$ and irradiance in excess of $2000 \mu \mathrm{mol}$ quanta $\mathrm{m}^{-2} \mathrm{~s}^{-1}$ for periods of 3 to $5 \mathrm{~d}$. ('thermal stress event', 
Table 2. Acropora aspera. (A) Multivariate and (B) univariate analyses testing the hypothesis that changes in symbiont densities in the days following a change in light intensity are independent of colour morph. Colour (B, blue; C, cream; LB, light blue; among-subject factor), Tank (3 tank-sets; within-subject factor), Day (d2, d5, d7; within-subject factor)

\begin{tabular}{|c|c|c|c|c|c|c|c|}
\hline \multicolumn{8}{|c|}{ (A) MANOVA for repeated measure based on Wilk's ${ }^{a}$} \\
\hline \multicolumn{2}{|c|}{ Source of variation } & Value & \multicolumn{2}{|c|}{$F$} & Effect df & Error df & $\mathrm{p}$ \\
\hline Day & & 0.2984 & & & 2 & 14 & 0.0002 \\
\hline Day $\times$ Colour & & 0.3599 & & & 4 & 28 & 0.0052 \\
\hline Tank & & 0.8189 & & & 2 & 14 & 0.2470 \\
\hline Tank $\times$ Colour & & 0.7240 & & & 4 & 28 & 0.3219 \\
\hline Day $\times$ Tank & & 0.6247 & & & 4 & 12 & 0.1932 \\
\hline Day $\times$ Tank $\times$ Colour & & 0.2551 & & & 8 & 24 & 0.0193 \\
\hline \multicolumn{8}{|c|}{ (B) ANOVA for repeated measures ${ }^{\mathrm{a}}$} \\
\hline Source of variation & SS & df & MS & $F$ & $\mathrm{p}$ & SNK $(0$. & \\
\hline Colour & $1.36 \mathrm{E}+13$ & 2 & $6.80 \mathrm{E}+12$ & 28.56 & 0.0000 & $\mathrm{~B}>\mathrm{LB}>$ & \\
\hline S/Colour ${ }^{b}$ & $3.57 \mathrm{E}+12$ & 15 & $2.38 E+11$ & & & & \\
\hline Day & $3.89 \mathrm{E}+12$ & 2 & $1.95 \mathrm{E}+12$ & 13.20 & 0.0001 & \multirow{2}{*}{\multicolumn{2}{|c|}{$\begin{array}{l}\text { Day } 7>_{0.033} \text { Day } 5=\text { Day } 2 \\
\operatorname{LB}_{(\text {Day } 7)}>_{0.015} \operatorname{LB}_{(\text {Day } 2)}\end{array}$}} \\
\hline Day $\times$ Colour & $3.78 \mathrm{E}+12$ & 4 & $9.45 \mathrm{E}+11$ & 6.41 & 0.0008 & & \\
\hline Day $\times$ S/Colour & $4.42 \mathrm{E}+12$ & 30 & $1.47 \mathrm{E}+11$ & & & & \\
\hline Tank & $2.47 \mathrm{E}+11$ & 2 & $1.23 \mathrm{E}+11$ & 0.87 & 0.4288 & & \\
\hline Tank $\times$ Colour & $8.13 E+11$ & 4 & $2.03 E+11$ & 1.44 & 0.2463 & & \\
\hline Tank $\times$ S/Colour & $4.24 \mathrm{E}+12$ & 30 & $1.41 \mathrm{E}+11$ & & & & \\
\hline Day $\times$ Tank & $1.17 \mathrm{E}+12$ & 4 & $2.92 \mathrm{E}+11$ & 1.24 & 0.3025 & & \\
\hline Day $\times$ Tank $\times$ Colour & $4.98 \mathrm{E}+12$ & 8 & $6.22 \mathrm{E}+11$ & 2.65 & 0.0146 & \multirow{2}{*}{\multicolumn{2}{|c|}{$\begin{array}{l}\mathrm{LB}_{(\text {Day7,Tank1) }}>_{0.015} \mathrm{LB}_{(\text {Day2, Tank1) }} \\
\mathrm{LB}_{(\text {Day7,Tank1) }}>_{0.007} \mathrm{LB}_{(\text {Day2, Tank3 }}\end{array}$}} \\
\hline Day $\times$ Tank $\times$ S/Colour & $1.41 \mathrm{E}+13$ & 60 & $2.35 \mathrm{E}+11$ & & & & \\
\hline
\end{tabular}

Table 3. Acropora aspera. (A) Multivariate and (B) univariate analyses testing the hypothesis that changes in photosynthetic efficiency in the days following a change in light intensity are independent of colour morph. Colour (B, blue; $C_{1}, c_{e a m}$ LB, light blue; among-subject factor), Tank (3 tank-sets; within-subject factor), Day (d2, d5, d7; within-subject factor)

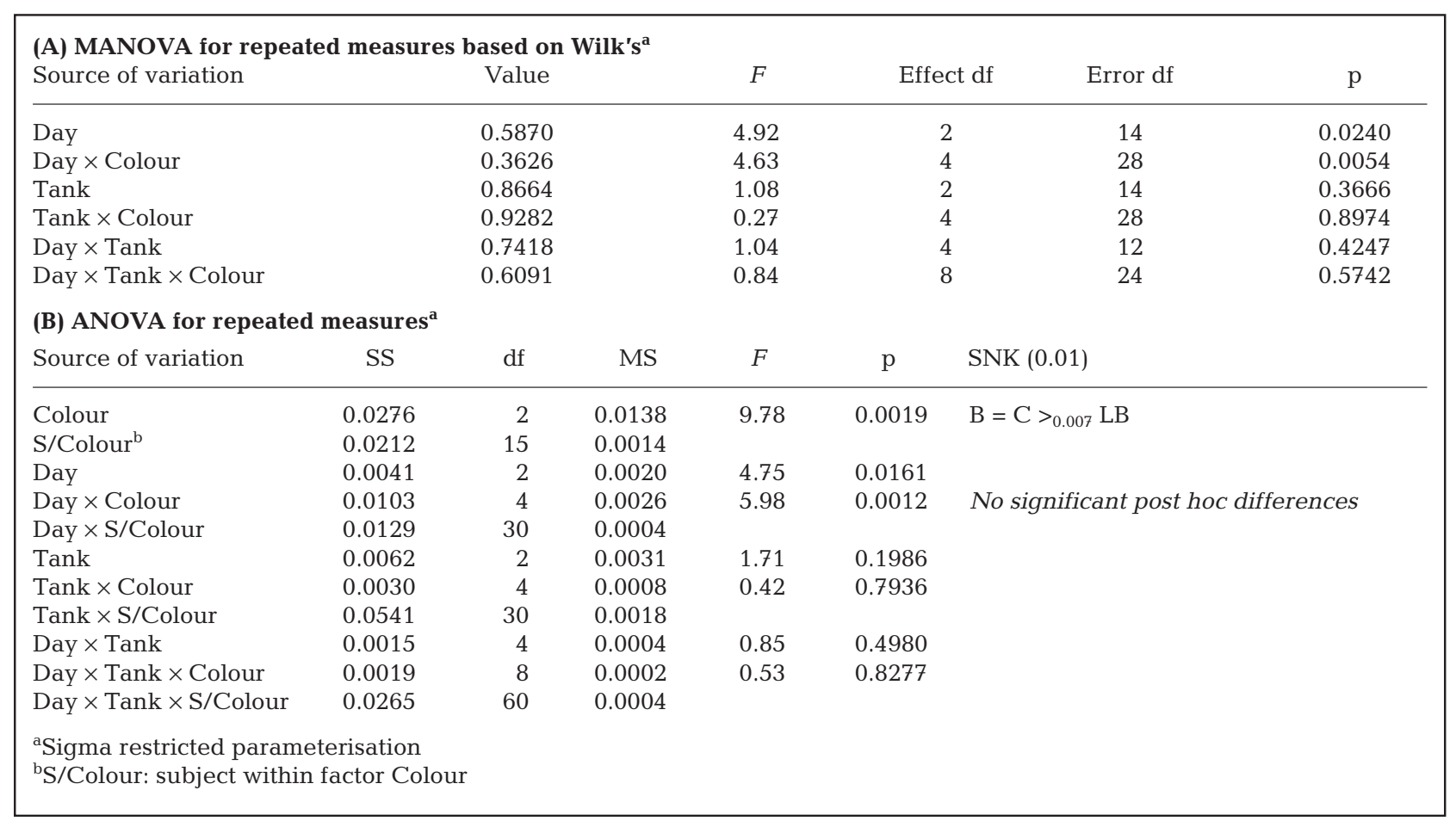


Fig. 4B-D). These periods of high water temperature coincided with midday low tides occurring within a 10:00 $\mathrm{h}$ to $17: 00 \mathrm{~h}$ time period (Fig. 4B-D). Data from loggers, weather reports and tide charts support the observation that there may have been as many as 4 'ther- mal stress events' on the Heron Island reef flat between 6 January and 8 March. These were around the dates of 10 January (Fig. 4B), 24 January (no data), 9 February (Fig. 4C) and 22 February 2002 (Fig. 4D). The $7 \mathrm{~d}$ 10:00 $\mathrm{h}$ to 17:00 h mean temperature and light intensities for 3
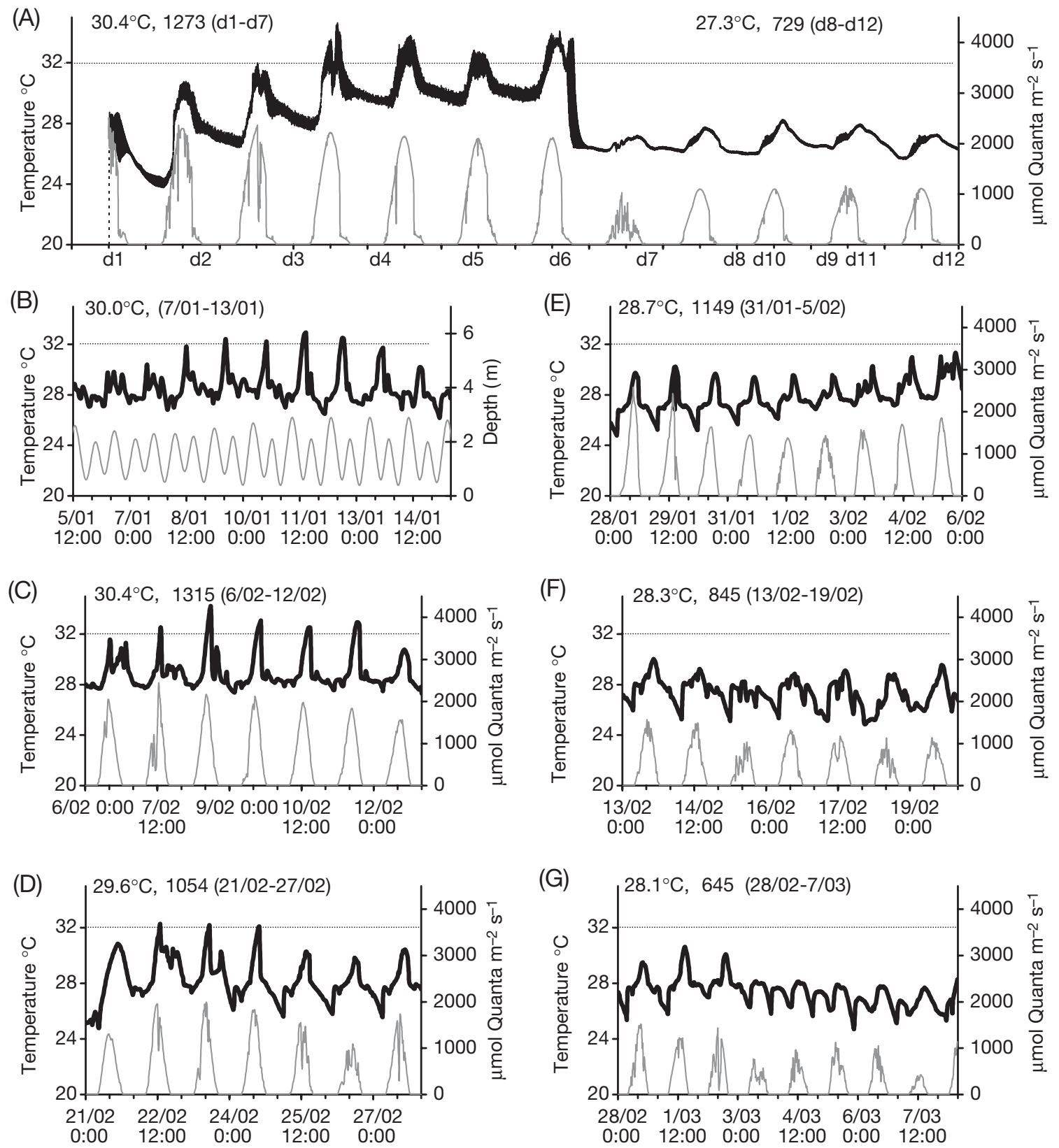

Fig. 4. Comparison of experimental and field temperature and light data for Heron Island reef flat during the 2002 mass bleaching event. (A) Experimental data. Temperature (above) shows the mean $\pm 95 \%$ confidence intervals for the 3 heated tanks; d1, unheated; $\mathrm{d} 2,+2^{\circ} \mathrm{C}_{i} \mathrm{~d} 3,+3{ }^{\circ} \mathrm{C} ; \mathrm{d} 4-\mathrm{d} 7,+4^{\circ} \mathrm{C}_{;} \mathrm{d} 8-\mathrm{d} 12$, unheated and shaded. Light data (below) was collected $2 \mathrm{~m}$ above the experimental tanks and has been corrected for an attenuation coefficient of $0.3 \mathrm{~m}^{-1}$, and a water depth of $0.3 \mathrm{~m}$ (Jerlov 1976). (B-G) Field data. (B-D) Intervals corresponding to high light, spring low tides; in B, tidal data is provided on secondary $y$-axis instead of light data. (E-G) Intervals corresponding to low light, low tides. Temperature and light loggers were placed vertically in the field, adjacent to collected colonies. Tidal data was provided by Heron Island Research Station. Mean 10:00 h to 17:00 h temperature and light data are shown for bracketed intervals. Dates are given as d/mo 
of these events were $30^{\circ} \mathrm{C}$ ( 7 to $13 \mathrm{Jan}$, Fig. $\left.4 \mathrm{~B}\right), 30.4^{\circ} \mathrm{C}$ and $1315 \mu \mathrm{mol}$ quanta $\mathrm{m}^{-2} \mathrm{~s}^{-1}$ (6 to 12 Feb, Fig. $4 \mathrm{C}$ ), and $29.6^{\circ} \mathrm{C}$ and $1054 \mu \mathrm{mol}$ quanta $\mathrm{m}^{-2} \mathrm{~s}^{-1}$ (21 to $27 \mathrm{Feb}$, Fig. $4 \mathrm{C}$ ). These events were interspersed with periods of lower mean 10:00 h to 17:00 h light intensity and/or temperature that resulted from a lack of coincidence between high-light conditions and low tide (Fig. E-G). A comparison between experimental and field physical data shows that mean experimental and light data are similar to conditions experienced in the field in early February 2002 $\left(30.4^{\circ} \mathrm{C}, 1300 \mu \mathrm{mol}\right.$ quanta $\mathrm{m}^{-2} \mathrm{~s}^{-1}$, Fig. $4 \mathrm{~A}$ $\&$ C). Post experimental recovery conditions were cooler and more prolonged (41 d, data provided for first $5 \mathrm{~d}$ only, Fig. 4A) than any of the short breaks from light and heat experienced in the field (Fig. 4E-G).

\section{Thermal response of the 3 colour morphs of Acropora aspera}

The initial 7 experimental days incorporated 3 paired tank sets such that one of the pair was heated (Heated) above the other (Control) by a fixed amount (0 to $4 \pm$ $0.5^{\circ} \mathrm{C}$ ). A heating error margin of $\pm 0.5^{\circ} \mathrm{C}$ did not guarantee that heated tanks showed identical temperature profiles. The information obtained from the temperature loggers showed that heating was variable across the 3 tank set-ups. Heated Tank 1 showed a mean 10:00 h to $17: 00 \mathrm{~h}$ temperature of $30.0^{\circ} \mathrm{C}$ over the 7 initial days of the experiment (d1-d7). This was different from mean temperatures of 30.4 and $30.9^{\circ} \mathrm{C}$ obtained for Heated Tanks 2 and 3 respectively (Fig. 5A). Noticeably, in the case of the blue morph, mortality rates (for heated compared to control) increased with tank temperature. All the blue explants from Tank 3 were dead by experimental Day 48 (0 deaths in control), $2 / 3$ died in Tank 2 ( 0 deaths in control) and an equivalent number to controls died in Tank 1 (Fig. 5B1). Light blue and cream morphs showed a good ability to recover from high temperature stress with mortality equivalent to or less than controls (Fig. 5B2, B3).

All colour morphs of Acropora aspera showed decreases in photosynthetic efficiency with increases in and maintenance at high temperature. Minimal values

\section{(A)
0
0
0
$\stackrel{0}{5}$
$\stackrel{ \pm}{0}$
$\frac{0}{0}$
$\frac{0}{E}$
$\stackrel{0}{\odot}$}

(B1)

(B2)

(B3) occurred on Day 7, prior to the shift to a shaded nonheated tank (Fig. 5B1, B2, B3). Repeated measure univariate and multivariate analyses of variance with among-subject factor 'Colour' and within-subject factors 'Temp' and 'Tank' were set up to test the null hypothesis that differences in symbiont densities and photosynthetic efficiencies on experimental Day 7 resulting from different temperature regimes are inde-
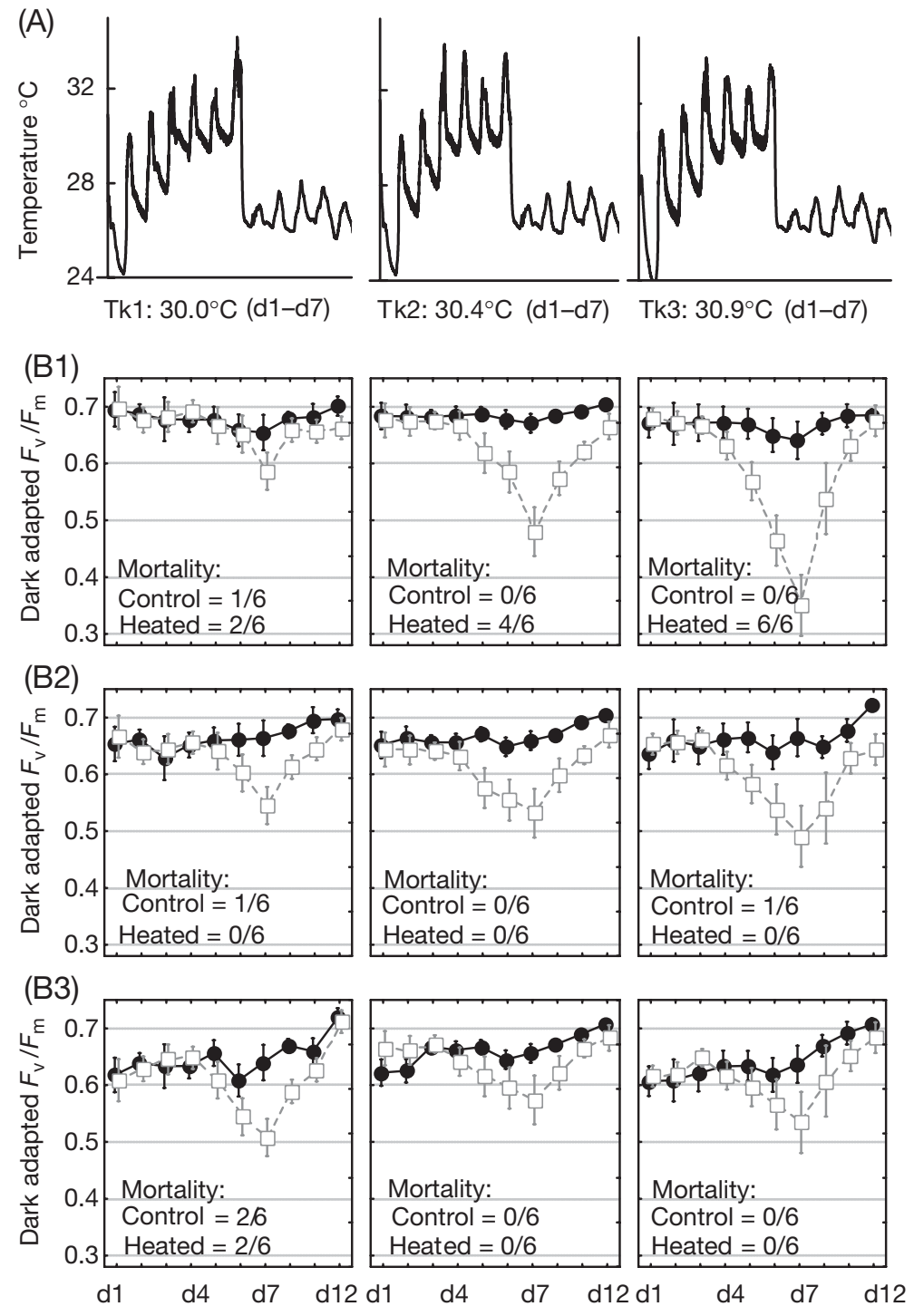

Fig. 5. Acropora aspera. Photosynthetic efficiency measured as dark adapted $F_{\mathrm{v}} / F_{\mathrm{m}}$ by a diving PAM fluorometer, approximately $2 \mathrm{~cm}$ from the tip for heated $(\square)$ and control $(\bullet)$ tanks during the experiment. (A) Temperature profiles from Heated Tanks 1, 2 and 3 over 12 experimental days (d1-d12). Mean 10:00 h to 17:00 h temperature data for individual tanks are shown for bracketed intervals. (B1-B2) Dark adapted $F_{\mathrm{v}} / F_{\mathrm{m}}$ corresponding to Tank Sets 1-3 for the 3 colour morphs. (B1) Blue, (B2) cream, (B3) light blue. Explant mortality specific to tank and colour morph after a further $36 \mathrm{~d}$ in recovery conditions (d48) is provided for control and heated tanks. Error bars represent $95 \%$ confidence intervals, Tk tank. Data is offset on the $x$-axis for clarity 
Table 4. Acropora aspera . (A) Multivariate and (B) univariate analyses testing the hypothesis that differences in photosynthetic efficiencies on experimental Day 7 resulting from different temperature regimes is are independent of colour morph. Colour (B, blue; C, cream; LB, light blue morphs; among-subject factor), Tank (3 tank-sets;,within-subject factor), Temp (control and heated; within-subject factor)

\begin{tabular}{|c|c|c|c|c|c|c|c|c|}
\hline \multicolumn{5}{|c|}{ A) MANOVA for repeated measure based on Wilk's ${ }^{a}$} & \multirow[b]{2}{*}{$F$} & \multirow[b]{2}{*}{ Effect df } & \multirow[b]{2}{*}{ Error df } & \multirow[b]{2}{*}{$\mathrm{p}$} \\
\hline Source of variation & & & lue & & & & & \\
\hline Tank & & & 013 & & 10.44 & 2 & 14 & 0.0017 \\
\hline Tank $\times$ Colour & & & 697 & & 6.48 & 4 & 28 & 0.0008 \\
\hline Temp & & & 322 & & 450.39 & 1 & 15 & 0.0000 \\
\hline Temp $\times$ Colour & & & 022 & & 11.15 & 2 & 15 & 0.0011 \\
\hline Tank $\times$ Temp & & & 214 & & 9.61 & 2 & 14 & 0.0024 \\
\hline Tank $\times$ Temp $\times$ Colour & & & 197 & & 5.38 & 4 & 28 & 0.0024 \\
\hline \multicolumn{9}{|c|}{ B) ANOVA for repeated measure ${ }^{a}$} \\
\hline Source of variation & SS & $\mathrm{df}$ & MS & $F$ & $\mathrm{p}$ & \multicolumn{3}{|c|}{ SNK $(0.05)$ of Tank $\times$ Temp $\times$ Colour } \\
\hline Colour & 0.0191 & 2 & 0.0095 & 3.80 & 0.0461 & \multirow{2}{*}{\multicolumn{3}{|c|}{ Heated $<$ control $\left(\right.$ eg. $\left.\mathrm{B}_{(\text {heated, Tank1) }}<_{0.046} \mathrm{~B}_{(\text {control, Tank1) }}\right)$}} \\
\hline S/Colour ${ }^{b}$ & 0.0376 & 15 & 0.0025 & & & & & \\
\hline Tank & 0.0478 & 2 & 0.0239 & 12.58 & 0.0001 & \multirow{6}{*}{\multicolumn{3}{|c|}{$\begin{array}{l}\mathrm{B}_{\text {(heated, Tank1) }}>_{0.0002} \mathrm{~B}_{\text {(heated, Tank2) }}>_{0.0001} \mathrm{~B}_{\text {(heated, Tank3) }} \\
\mathrm{B}_{\text {(control, Tank1) }}={ }_{1.0} \mathrm{~B}_{\text {(control, Tank2) }}=_{0.9} \mathrm{~B}_{\text {(control, Tank3) }} \\
\mathrm{C}_{\text {(heated, Tank1) }}={ }_{0.8} \mathrm{C}_{(\text {heated, Tank2) }}={ }_{0.2} \mathrm{C}_{(\text {heated, Tank3) }} \\
\mathrm{C}_{\text {(control, Tank1) }}={ }_{0.9} \mathrm{C}_{\text {(control, Tank2) }}={ }_{1.0} \mathrm{C}_{\text {(control, Tank3) }} \\
\mathrm{LB}_{\text {(heated, Tank1) }}==_{0.06} \mathrm{LB}_{\text {(heated, Tank2) }}=_{0.2} \mathrm{LB}_{\text {(heated, Tank3) }} \\
\mathrm{LB}_{\text {(control, Tank1) }}={ }_{0.9} \mathrm{LB}_{(\text {control, Tank2) }}==_{0.9} \mathrm{LB}_{\text {(control, Tank3) }}\end{array}$}} \\
\hline Tank $\times$ Colour & 0.0635 & 4 & 0.0159 & 8.35 & 0.0001 & & & \\
\hline Tank $\times$ S/Colour & 0.0570 & 30 & 0.0019 & & & & & \\
\hline Temp & 0.5513 & 1 & 0.5513 & 450.39 & 0.0000 & & & \\
\hline Temp $\times$ Colour & 0.0273 & 2 & 0.0136 & 11.15 & 0.0011 & & & \\
\hline Temp $\times$ S/Colour & 0.0184 & 15 & 0.0012 & & & & & \\
\hline Tank $\times$ Temp & 0.0321 & 2 & 0.0161 & 10.02 & 0.0005 & & & \\
\hline Tank $\times$ Temp $\times$ Colour & 0.0516 & 4 & 0.0129 & 8.04 & 0.0002 & \multirow{2}{*}{\multicolumn{3}{|c|}{$\begin{array}{l}\mathrm{B}_{\text {(heated, Tank3) }}<<_{0.0007} \mathrm{C}_{\text {(heated, Tank3) }}={ }_{0.45} \mathrm{LB}_{\text {(heated, Tank3) }} \\
\mathrm{B}_{\text {(control, Tank3) }}={ }_{0.96} \mathrm{C}_{\text {(control, Tank3) }}==_{0.97} \mathrm{LB}_{\text {(heated, Tank3) }}\end{array}$}} \\
\hline Tank $\times$ Temp $\times$ S/Colour & 0.0481 & 30 & 0.0016 & & & & & \\
\hline
\end{tabular}

Table 5. Acropora aspera. (A) Multivariate and (B) univariate analyses testing the hypothesis that differences in symbiont densities on experimental Day 7 resulting from different temperature regimes is are independent of colour morph. Colour (B, blue; $\mathrm{C}$, cream; LB, light blue morphs; among-subject factor), Tank (3 tank-sets; within-subject factor), Temp (control and heated; within-subject factor)

\begin{tabular}{|c|c|c|c|c|c|c|c|c|}
\hline \multicolumn{6}{|c|}{ A) MANOVA for repeated measure based on Wilk's ${ }^{a}$} & \multirow[b]{2}{*}{ Effect df } & \multirow[b]{2}{*}{ Error df } & \multirow[b]{2}{*}{$\mathrm{p}$} \\
\hline Source of variation & & Valu & & $F$ & & & & \\
\hline \multicolumn{2}{|l|}{ Temp } & \multicolumn{2}{|c|}{0.0840} & \multicolumn{2}{|c|}{163.59} & 1 & 15 & 0.0000 \\
\hline \multicolumn{2}{|l|}{ Temp $\times$ Colour } & \multicolumn{2}{|c|}{0.1701} & \multicolumn{2}{|l|}{36.60} & 2 & 15 & 0.0000 \\
\hline \multicolumn{2}{|l|}{ Tank } & \multicolumn{2}{|c|}{0.6302} & \multicolumn{2}{|l|}{4.11} & 2 & 14 & 0.0395 \\
\hline \multicolumn{2}{|l|}{ Tank $\times$ Colour } & \multicolumn{2}{|c|}{0.3035} & \multicolumn{2}{|l|}{5.71} & 4 & 28 & 0.0017 \\
\hline \multicolumn{2}{|l|}{ Temp $\times$ Tank } & \multicolumn{2}{|c|}{0.7514} & \multicolumn{2}{|l|}{2.32} & 2 & 14 & 0.1352 \\
\hline \multicolumn{2}{|l|}{ Temp $\times$ Tank $\times$ Colour } & \multicolumn{2}{|c|}{0.9294} & \multicolumn{2}{|l|}{0.26} & 4 & 28 & 0.9004 \\
\hline \multicolumn{9}{|c|}{ B) ANOVA for repeated measure ${ }^{a}$} \\
\hline Source of variation & SS & df & MS & $F$ & $\mathrm{p}$ & SNK $(0 . C$ & & \\
\hline Colour & $8.85 \mathrm{E}+11$ & 2 & $4.43 \mathrm{E}+11$ & 6.01 & 0.0121 & $\mathrm{~B}=\mathrm{LB}>$ & & \\
\hline S/Colour ${ }^{b}$ & $1.10 \mathrm{E}+12$ & 15 & $7.36 \mathrm{E}+10$ & & & & & \\
\hline Tank & $1.25 \mathrm{E}+13$ & 1 & $1.25 \mathrm{E}+13$ & 163.59 & 0.0000 & & & \\
\hline Tank $\times$ Colour & $5.58 \mathrm{E}+12$ & 2 & $2.79 \mathrm{E}+12$ & 36.60 & 0.0000 & $\mathrm{~B}_{(\text {Tank1) }}>$ & (Tank3) & \\
\hline Tank $\times$ S/Colour & $1.14 \mathrm{E}+12$ & 15 & $7.62 \mathrm{E}+10$ & & & & & \\
\hline Temp & $9.29 \mathrm{E}+11$ & 2 & $4.65 \mathrm{E}+11$ & 3.49 & 0.0433 & Heated & Control & \\
\hline Temp $\times$ Colour & $3.39 \mathrm{E}+12$ & 4 & $8.46 \mathrm{E}+11$ & 6.36 & 0.0008 & $\mathrm{~B}_{\text {(heated) }}$ & $\mathrm{B}_{\text {(control); }} ; \mathrm{LB}$ & ${ }_{08} \mathrm{LB}_{\text {(control) }}$ \\
\hline Temp $\times$ S/Colour & $3.99 \mathrm{E}+12$ & 30 & $1.33 \mathrm{E}+11$ & & & & & \\
\hline Tank $\times$ Temp & $9.99 \mathrm{E}+11$ & 2 & $5.00 \mathrm{E}+11$ & 3.08 & 0.0607 & & & \\
\hline Tank $\times$ Temp $\times$ Colour & $1.49 \mathrm{E}+11$ & 4 & $3.73 E+10$ & 0.23 & 0.9194 & & & \\
\hline Tank $\times$ Temp $\times$ S/Colour & $4.87 \mathrm{E}+12$ & 30 & $1.62 E+11$ & & & & & \\
\hline
\end{tabular}


pendent of colour morph. Significant interactions between Tank, Temp and Colour were observed for photosynthetic efficiency data (multivariate, p < 0.0024 , Table 4A; univariate, $\mathrm{p}<0.0002$, Table 4B) suggesting that the null hypothesis should be rejected. All colour morphs had significantly reduced dark-adapted $F_{\mathrm{v}} / F_{\mathrm{m}}$ in heated treatments as compared to controls, but only the blue morph was responsive to the mean temperature difference that existed between the heated tanks (Table 4B, Fig. 3B). In the case of symbiont density, there was both a significant Tank and Colour interaction and a significant Temp and Colour interaction but no 3-way interaction (Table 5A,B). The blue morph was primarily responsible for the first interaction with significantly higher symbiont densities associated with this morph in Tank Set 1 than in Tank Set 3 (Table 5B). Both the blue and the light blue morphs are responsible for the interaction between Temp and Colour on Day 7 (Table 5B, Fig. 3A). In the blue morph, this distinction is driven by a decrease in symbiont densities associated with thermal stress. In the light blue morph, it results from an inability to recover symbiont densities when under thermal stress (Fig. 3A).

The long-term cellular responses to thermal stress after $41 \mathrm{~d}$ of recovery conditions were found to differ between the 3 morphs. The amount of tissue covering the skeleton was estimated using the total animal solu- ble protein per area. Animal soluble protein is commonly used to normalise dinoflagellate populations (e.g. Berner et al. 1993). As a result of high mortality in the blue morph by experimental Day 48, mean values across all 3 tanks were used for a 2-factorial (Colour, Temp) repeated measure ANOVA replicated across 6 colonies per colour morph. This revealed that the interaction between Colour and Temp was significant for both symbiont density data and total animal protein data $(p<0.0007$ and $p<0.0007$ respectively, Table 6 A, B; Fig. 6A,B). Post-hoc analyses showed that, even after prolonged recovery, heated blue explants had significantly less symbionts and animal protein than explants that were never subjected to elevated temperature. The cream morph showed no decrease in symbionts, but a slight though significant decrease in animal protein. The light blue morphs were unchanged (Table $6 \mathrm{~A}, \mathrm{~B}$; Fig. 6A,B). Analysis of the ratio of these 2 data sets (symbionts $\mathrm{mg}^{-1}$ of animal protein, Table $6 \mathrm{C}$ ) reveals a non-significant interaction $(p<0.11)$.

\section{Analysis of field data}

Five colonies were repetitively sampled on 6 January, 8 January and 8 March 2002 in order to test the null hypothesis that differences in symbiont densities over a bleaching event in the field are independent of

Table 6. Acropora aspera. Repeated measure ANOVAs using sigma parameterization testing the hypotheses that differences in symbiont densities (A, C) and total host water soluble protein (B) resulting from different temperature regimes after a prolonged recovery are independent of colour morph. Colour (B, blue; $C$, cream; LB, light blue morphs, among subject factor), Temp (control and heated, within subject factor)

\begin{tabular}{|c|c|c|c|c|c|c|}
\hline Source of variation & SS & $\mathrm{df}$ & MS & $F$ & $\mathrm{p}$ & SNK (0.05) \\
\hline \multicolumn{7}{|l|}{ (A) Symbiont $\mathrm{cm}^{-2}$} \\
\hline Colour & $1.05 \mathrm{E}+13$ & 2 & $5.24 \mathrm{E}+12$ & 35.15 & 0.0000 & \\
\hline S/Colour ${ }^{a}$ & $2.24 \mathrm{E}+12$ & 15 & $1.49 \mathrm{E}+11$ & & & \\
\hline Temp & $2.40 \mathrm{E}+12$ & 1 & $2.40 \mathrm{E}+12$ & 14.21 & 0.0019 & \\
\hline Temp $\times$ Colour & $4.10 \mathrm{E}+12$ & 2 & $2.05 \mathrm{E}+12$ & 12.16 & 0.0007 & $\mathrm{~B}_{\text {(heated) }}<_{0.0002} \mathrm{~B}_{\text {(control) }}$ \\
\hline Temp $\times$ S/Colour & $2.53 E+12$ & 15 & $1.69 \mathrm{E}+11$ & & & \\
\hline \multicolumn{7}{|c|}{ (B) Protein $\left(\mathrm{mg} \mathrm{cm}^{-2}\right)$} \\
\hline Colour & 82.57 & 2 & 41.28 & 13.58 & 0.0004 & \\
\hline S/Colour & 45.60 & 15 & 3.04 & & & \\
\hline Temp & 70.34 & 1 & 70.34 & 49.15 & 0.0000 & \\
\hline Temp $\times$ Colour & 34.85 & 2 & 17.42 & 12.18 & 0.0007 & $\mathrm{~B}_{\text {(heated) }}<_{0.0002} \mathrm{~B}_{\text {(control) }}$ \\
\hline Temp $\times$ S/Colour & 21.47 & 15 & 1.43 & & & $\mathrm{C}_{\text {(heated) }}<_{0.012} \mathrm{C}_{\text {(control) }}$ \\
\hline \multicolumn{7}{|c|}{ (C) Symbionts ( $\mathrm{mg}^{-1}$ protein) } \\
\hline Colour & $2.15 \mathrm{E}+10$ & 2 & $1.08 \mathrm{E}+10$ & 9.81 & 0.0019 & \\
\hline S/Colour & $1.65 \mathrm{E}+10$ & 15 & $1.10 \mathrm{E}+09$ & & & \\
\hline Temp & $1.66 \mathrm{E}+07$ & 1 & $1.66 \mathrm{E}+07$ & 0.01 & 0.9353 & \\
\hline Temp $\times$ Colour & $1.24 \mathrm{E}+10$ & 2 & $6.18 \mathrm{E}+09$ & 2.53 & 0.1128 & \\
\hline Temp $\times$ S/Colour & $3.66 \mathrm{E}+10$ & 15 & $2.44 \mathrm{E}+09$ & & & \\
\hline
\end{tabular}





Fig. 6. Acropora aspera. Properties of heated and control corals after a $41 \mathrm{~d}$ unheated recovery period in the shade. (A) Symbiotic algal densities per surface area of a $2 \mathrm{~cm}$ cylinder. (B) Total protein per surface area. (C) Symbionts per total soluble animal protein. Error bars represent $95 \%$ confidence intervals. Data is offset on the $x$-axis for clarity

colour morph. Multivariate and univariate repeated measure analyses of symbiont density $\left(\mathrm{cm}^{-2}\right.$ and $\mathrm{mg}^{-1}$ animal soluble protein) data revealed significant interactions between Time and Colour (multivariate, $\mathrm{p}<0.029, \mathrm{p}<0.031$ respectively, Table 7A, ; univariate, $\mathrm{p}<0.0015, \mathrm{p}<0.0032$ respectively, Table 7B,D, Fig. 7A,B). Post hoc analysis revealed that the rejection of the null hypothesis was driven by a significant decrease in symbiont densities $\left(\mathrm{cm}^{-2}\right)$ between early January and early March for the blue and light blue morphs, but not for the cream morph of Acropora aspera (Table 7A, Fig. 7A). Similar post-hoc results were obtained for symbionts normalised to animal protein (Table 7B, Fig. 7B).

\section{DISCUSSION}

This study set out to test whether host tissue pigments, specifically GFP-homologues (inclusive of pocilloporins) reduced coral bleaching in response to thermal stress. Recent articles have argued that bleaching resistance would follow from the photoprotection offered by these pigments to resident algal symbionts (Hoegh-Guldberg 1999, Salih et al. 2000). Salih et al. (2000) showed that strongly fluorescent morphs of Acropora palifera (measured under blacklight excitation [320 to $420 \mathrm{~nm}$ ]) underwent less photoinhibition during the course of a day than weakly or non-fluorescent morphs and concluded that this was due to the presence of host pigment. Host pigments were, however, limited to those that fluoresced under black light illumination and did not include the multitude of pigments that absorb light but are not fluorescent. Red-shifted non-fluorescent GFP-homologues may be important to symbiont photoprotection, because as immature (or newly formed) protein they
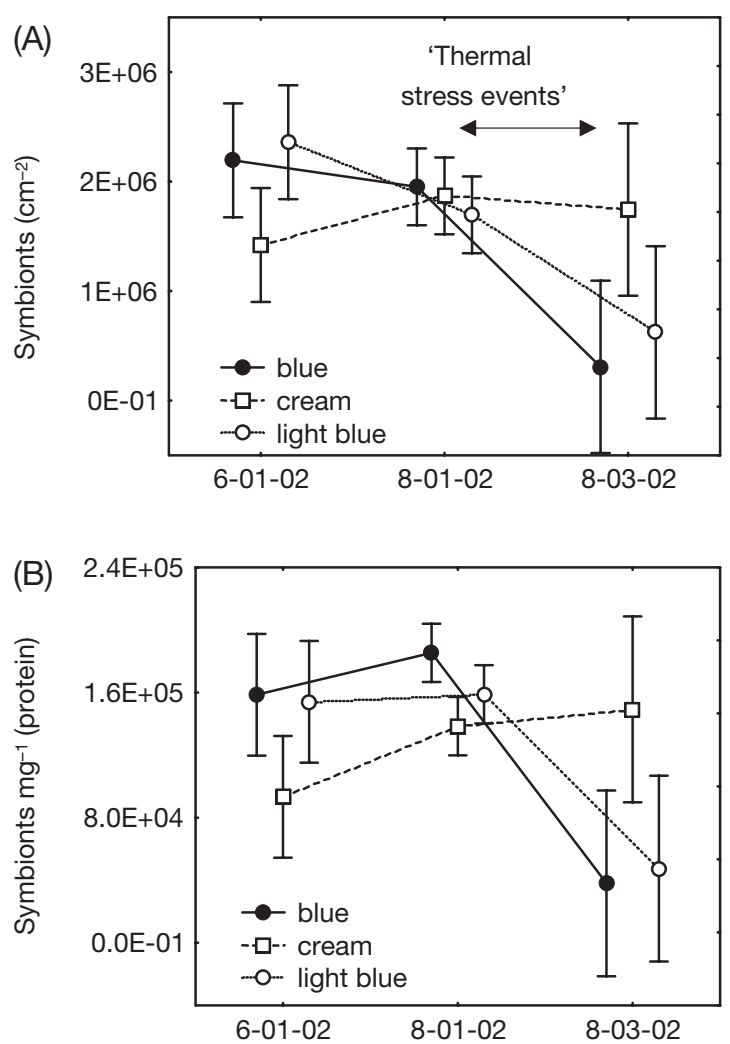

Fig. 7. Acropora aspera. Field data for blue, cream and light blue morphs over the 2002 mass bleaching event on the Great Barrier Reef. (A) Algal densities per surface area of a $2 \mathrm{~cm}$ coral cylinder. (B) Algal densities normalised to total animal soluble protein. Error bars represent $95 \%$ confidence intervals. Data is offset on the $x$-axis for clarity. Dates are given as $\mathrm{d} / \mathrm{mo} / \mathrm{yr}$ 
Table 7. Acropora aspera. (A,C) Multivariate and (B,D) univariate analyses testing the hypothesis that differences in symbiont densities (normalised to $[\mathrm{A}, \mathrm{B}] \mathrm{mg}$ protein or $[\mathrm{C}, \mathrm{D}]$ surface area) over a bleaching event in the field are independent of colour

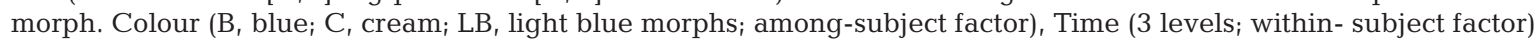

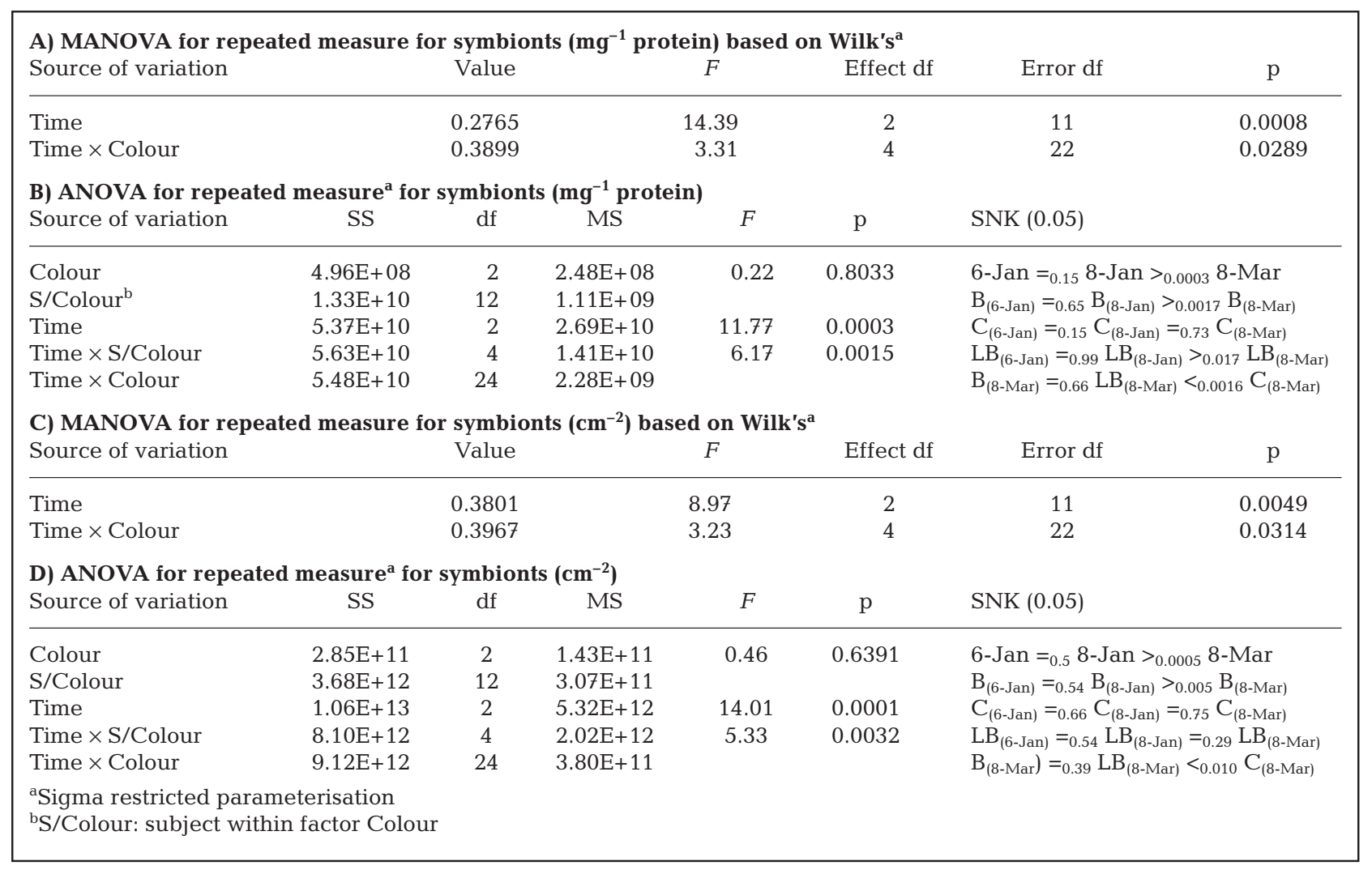

absorb efficiently across the Soret band of chlorophyll (Gross et al. 2000, Prescott et al. 2003). Photoprotection has not been demonstrated for non-fluorescent host pigments, therefore their potential role as photoprotectants to endosymbionts was examined prior to investigating whether they rendered the coral less susceptible to thermal bleaching.

\section{Absorption versus fluorescence and photoprotection}

The principal property of a photoprotectant is its ability to absorb potentially harmful energy. The methods that a pigment uses to dispose of this energy (only one of which is fluorescence) are of secondary importance. Despite this, fluorescent output is used by many investigators, for example, to quantify GFP abundance (Salih et al. 2000), or to screen for inclusion in a phylogenetic analysis of GFP origin and function (Labas et al. 2002). Recently, Mazel et al. (2003) showed that only 1 of 9 pair-wise comparisons of strongly and weakly fluorescent corals from the Caribbean demonstrated a greater ability of the strongly fluorescent coral to remove photons from chlorophyll excitation and, hence, to provide a photoprotective role. The ability to remove photons is a function of the absorption properties of pigments, yet the corals were contrasted according to their fluorescent intensities. The results of the Mazel et al. (2003) study could be interpreted as demonstrating that the ability of a GFP-homologue to absorb light (extinction coefficient) is not correlated to the strength of fluorescent emission (quantum yield). Such an interpretation is more consistent with laboratory-derived data (Gurskaya et al. 2001, Bulina et al. 2002, S. Dove et al. unpubl.), than the alternative conclusion that GFP-homologues do not provide a photoprotective role (Mazel et al. 2003). In the laboratory, single point mutations have been shown to enhance or eliminate fluorescence, whilst maintaining absorption properties (Gurskaya et al. 2001, Bulina et al. 2002, S. Dove et al. unpubl.). In addition, the total concentration of GFP-homologues in coral tissue may not be a good indication of whether these proteins play a photoprotective function. Experience with bacterially expressed GFP-homologues has shown that the extinction coefficients and spectra are highly variable among proteins that are 99.5 to $20 \%$ identical in amino acid sequence (Dove et al. 2001b, Bevis \& Glick 2002, 
Prescott et al. 2003). For these reasons, the colour morphs of Acropora aspera were compared and contrasted primarily according to their ability to absorb photosynthetically active radiation (PAR).

\section{Properties of the different colour morphs of Acropora aspera}

The major colour morphs of Acropora aspera are ideal for examining the role of host pigments in bleaching resistance because they are known to be a single host species (van Oppen et al. 2001a) in which a single clade of symbiotic algae resides (van Oppen et al. 2001b). This study confirmed that C3 (sensu LaJeunesse 2001) is hosted in the diverse colour morphs of shallow water $A$. aspera examined. The corals were also collected from the same light history on the Heron Island reef flat, with the same sun-exposed regions being used in all experiments. The important point here is that the differences in photoprotective properties or bleaching susceptibility among the different colour morphs of $A$. aspera were not driven by previous external light history or the presence of different clades or subclades of symbiotic algae (Rowan et al. 1997, Banaszak et al. 2000, Jones \& HoeghGuldberg 2001, Brown et al. 2002).

Coral colour is determined by the dominant spectral characteristics of a range of GFP-homologues that occur within host tissue (Dove et al. 1995, Dove et al. 2001a, Labas et al. 2002). Green fluorescent branches, from light blue colonies, were included in this part of the study to demonstrate that, although these branches were as strongly coloured as branches from the blue morph, their ability to absorbed energy across the entire visible range was significantly less than that of blue branches and similar to the less colourful morphs. The blue morph of Acropora aspera not only absorbed more visible light energy than the other colour morphs, but also contained the highest quantity of total GFPhomologues (Fig. 1). The blue coloration was due to a specific sub-family of blue pocilloporins $\left(\lambda_{\max }=\right.$ 560-593 nm with amino acid identity of $93-100 \%$, Dove et al. 2001b), enhanced by the presence of a blue fluorescent GFP-homologue $(420 \mathrm{~nm}$ excitation, $500 \mathrm{~nm}$ emission; Dove et al. 2001) or immature pocilloporins absorbing across the Soret band of chlorophyll (Prescott et al. 2003).

The light blue morph was visibly pigmented only at the axial polyp. Visible pigmentation did not extend down to the $2 \mathrm{~cm}$ cylinder that was analyzed for darkadapted $F_{\mathrm{v}} / F_{\mathrm{m}}$, symbiont densities $\left(\mathrm{cm}^{-2}\right)$ and total animal soluble protein. Host pigment analysis was applied to the full branch length $(3 \mathrm{~cm})$ inclusive of the axial polyp and should therefore overestimate the pigment content of the cylinder. Despite this overestima- tion, light blue morphs had significantly less total GFP than the cream or blue morphs (Fig. 1B). Furthermore, the absorbance spectrum of the light blue morph was indistinguishable from that of the cream morph and significantly different from that of the blue morph (Fig. 1A). On the basis of soluble host pigment, it would appear that of all the colour morphs, blue Acropora aspera has the greatest potential to remove electrons from chlorophyll excitation.

\section{Photoprotective properties of the blue morph}

The irradiance incident on corals is highly variable and algal symbionts have some versatility with respect to their ability to acclimatise to low or high light levels. Typical responses to shade-acclimation include increases in the photosynthetic pigments within algal symbionts and/or increases in algal symbiont density (Falkowski \& Dubinsky 1981). Under extremely high light intensity, symbiotic algae activate a series of biochemical 'quenching' mechanisms that divert energy away from processing by the photochemical pathways of photosynthesis (Mazel et al. 2003). The mechanisms invoked are related to the cycling between epoxycontaining and epoxy-free xanthophylls described for higher plants and marine algae (Franklin et al. 1996, Brown et al. 1999). The induction of these photoprotective mechanisms can be monitored through a decrease in dark-adapted $F_{\mathrm{v}} / F_{\mathrm{m}}$ values, driven by decreases in both $F_{\mathrm{m}}$ and $F_{\mathrm{o}}$ values (Krause \& Weis 1991).

The blue morph of Acropora aspera maintained high algal densities and high photosynthetic efficiency $\left(F_{\mathrm{v}} / F_{\mathrm{m}}\right)$ when faced with a $78 \%$ increase in light intensity (daytime means increasing from $730 \mu$ mol quanta $\mathrm{m}^{-2} \mathrm{~s}^{-1}$ to $1270 \mu \mathrm{mol}$ quanta $\mathrm{m}^{-2} \mathrm{~s}^{-1}$ ). This contrasted sharply with the response of cream and light blue morphs. Noticeably, dark-adapted $F_{\mathrm{v}} / F_{\mathrm{m}}$ in corals experiencing a shift to high irradiance positively correlated with GFP concentration (cf. Figs. 1B \& 2A). Longterm and subtle decreases in $F_{\mathrm{v}} / F_{\mathrm{m}}$ have been discussed in terms of photoinhibition and are believed to be associated with the activation of non-photochemical quenching (Krause \& Weis 1991). Alternatively, decreases in $F_{\mathrm{v}} / F_{\mathrm{m}}$ for dark-adapted samples may represent a decline in the population of functional reaction centres of PSII as a result of photodamage (Osmond et al. 1999). The light blue and cream morphs both experienced significant, but long-term, decreases in $F_{\mathrm{v}} / F_{\mathrm{m}}$ suggesting that symbionts either (1) activated some form of non-photochemical quenching in the high light environment that did not fully relax with dark adaptation; or (2) incurred damage to their reaction centres (Fig. 2A, Fig. 5B2,3). Variability in $F_{\mathrm{v}} / F_{\mathrm{m}}$ for control explants was greater in the light blue and 
cream morphs than in the heavily pigmented blue morph throughout the course of the experiment. Furthermore, $F_{\mathrm{v}} / F_{\mathrm{m}}$ steady improvement was not evident until corals were returned to the shade (Fig. 5B2,3). It would appear that symbionts inside blue hosts do not experience the variability in external light conditions (and hence do not have to activate non-photochemical quenching mechanisms or incur photodamage) as much as symbionts residing in less pigmented morphs.

A protein pigment can operate as a shade in one of 2 ways: (1) by maintaining a constant quantity of mature pigment protein, (2) by varying protein turnover and maturation rates according to an environmental stimulus (e.g. light). Although not directly demonstrated in the current study, the observation of decreased photoinhibition within the blue morph highlights the possibility that light modulation of shade (i.e. shade that changes in response to changes in irradiance) may be occurring. A fixed shade would effectively screen the resident algae from extremely high levels of irradiance. It would not, however, reduce the impact of changing light intensity. Prolonged shadeacclimation results in increases in the photosynthetic pigments within algal symbionts (Falkowski \& Dubinsky 1981). These increases make the photosynthetic apparatus more efficient at capturing photic energy and therefore similarly sensitive to reduced amplitude variable light. Efficient light-modulating host pigments would reduce photoinhibition, as symbionts would no longer experience significant daily light fluctuation, despite becoming shade-acclimated.

The potential for host pigments to act as light-sensitive shading mechanisms was first suggested by Takabayashi \& Hoegh-Guldberg (1995), who showed that the amount of pink pocilloporin in Pocillopora damicormis was increased by exposure to photosynthetic (but not ultraviolet) irradiance. The role of host pigments as photoprotectants has always been questioned on the grounds that there is no evidence that host pigments correlate with high-light or shallow habitats (Takabayashi \& Hoegh-Guldberg 1995). The presumption is that pigments are present as fixed shades to block out high irradiance. Viewed as light modulators, host pigments are advantageous to corals living at depths and under overhangs, because the quality of light attaining the coral surface is variable even in these environments (Anthony \& Hoegh-Guldberg 2003). Furthermore, if chromophore induction and maturation were dependant on light, then tissues with reduced algal densities would have stimulated pigmentation due to less light absorption by the algae. This may explain why the axial polyps are frequently more pigmented than the rest of the coral (e.g. light blue Acropora aspera) and, equally, why corals frequently appear to be more colourful following bleaching events.
In this context, it is intriguing to note that host tissue swings from a state of hypoxia at night to one of hyperoxia during the day (Kuhl et al. 1995). In the absence of $\mathrm{O}_{2}$, synthesis and protein-folding of GFP-homologues can occur, but the chromaphore cannot mature (Tsien 1998). Light activates photosynthesis and introduces $\mathrm{O}_{2}$ into the host tissues, with the result that chromaphore maturation can be completed to produce host proteins that are capable of absorbing visible light. In this sense at least, light can control chromophore maturation in scleractinian corals. In the case of the GFP-homologues DsRed and pocilloporins, the first oxygenation steps provide a molecule that absorbs UVA and blue light. It is a second oxygenation step, absent from wild type GFP, that red-shifts the absorption spectra (Gross et al. 2000, Prescott et al. 2003). Transient absorption over the Soret band may be a useful feature for modulating the impact of light on endosymbionts, especially if the maturation rate is responsive to light levels. GFP-homologues that code for $99 \%$ identical amino-acid sequences exhibit different $5^{\prime}$ UTR and N-terminal residues (Dove et al. 2001b). Differences in these regions can lead to differential protein targeting or turnover rates (Stryer 1988). A range of experiments are required to examine the many features of GFP-homologues. The first and most obvious set of experiments are those determining the turnover rates and transition state residence times in response to changes in illumination. GFP-homologues are remarkable molecules that exhibit a diverse range of features. The ability to fluoresce is certainly functionally significant in the hydrozoan jelly fish Aequorea victoria example, which is fluorescently coupled with luciferin to produce a more advantageous quality of downwelling light (Morin \& Hastings 1971). However we need to be careful not to assume that this is the feature that drives the presence of such proteins in a holosymbiont.

\section{Thermal tolerance of the blue morph}

Corals exposed to temperatures of 32 to $34^{\circ} \mathrm{C}$ show a decrease in the quantum yield of photosynthesis (dark adapted $F_{\mathrm{v}} / F_{\mathrm{m}}$, Jones et al. 1998, Warner et al. 1999) and the loss of functional D1 photosynthetic reaction centre protein (Warner et al. 1999). The expectation, based on the current model of thermal bleaching, is that host pigments would act to reduce the energy input into photosynthesis and hence reduce the rate at which active oxygen is generated. Heavily pigmented corals such as the blue morph should therefore be less susceptible. This study has demonstrated the diametric opposite, however, for both experimental and fieldbased corals. After a month of recovery, previously 
heated blue morphs died or maintained less tissue cover (determined as animal soluble protein; Berner et al. 1993) and algal densities $\left(\mathrm{cm}^{-2}\right)$ than unheated controls. Interestingly, in this case death increased uniformly with tank temperature (Fig. 5B1). Fortunately for the repeated measures analysis, the 4 colonies that survived in Heated Tank 1, were distinct from the 2 colonies that survived in Tank 2 . The reductions of $50 \%$ in protein (and symbionts) in the blue morph observed after a month of recovery were attributable $(2 / 3)$ to explants from Heated Tank 1 that showed relatively mild decreases in photosynthetic efficiency by the last day of heating (d7, Figs. 3B, 5 \& 6B). A possible interpretation is that, in the case of the blue morph, damage to the host cell preceded damage to symbiont photosystems. This, however, goes beyond these results and requires the analysis of protein concentrations, carbon translocation from symbiont to host, and tissue sections taken during the thermal treatments. The loss of tissue biomass can be explained either by host cell detachment (Gates et al. 1992, Dunn et al. 2002) or by a reduction in translocated carbon from the remaining symbionts (Leggat et al. 2003).

Dramatic loss of animal soluble protein appears to be a severe response to a temperature increase, given that it results in coral mortality. The severity of the response in the most pigmented corals in this study suggests a couple of non-exclusive possible explanations: (1) Host pigment photoprotection is susceptible to temperature increases; (2) Potential products from host pigment chromophore maturation inhibit superoxide scrubbing enzymes such as CuZn-superoxide dismutase (CuZnSOD). Some evidence of both can be drawn from the current literature. More research is required however, to establish whether these options hold. In vitro, host pigments isolated from anthozoans display slow maturation rates that are susceptible to temperature and require molecular oxygen in the final phase of maturation (Tsien 1998, Matz et al. 1999, Baird et al. 2000, S. Dove et al. unpubl.). As unfolded protein is likely to be susceptible to rapid degradation, in vivo protein folding may be assisted by the presence of a constitutive chaperone such as Hsp 90 (Makino et al. 1997, Queitsch et al. 2002). With the cooperation of chaperonins, small increases in temperature could lead to increased host pigment degradation or to increased concentrations of folded protein (Weissman et al. 1996, Makino et al. 1997). In vitro, host pigments show a tendency to aggregate and precipitate out of solution at high concentration (void volume in gel filtration chromatogram absorbed at $580 \mathrm{~nm}$, data not shown, Fig. 1B). Furthermore, initial studies by C. Smith (pers. comm.) suggests that GFP mRNA is unstable in vivo at temperatures as low as $32^{\circ} \mathrm{C}$. The evidence suggests that subtle temperature increases could have severe and detrimental affects on a photoprotective mechanism that is dependant on control of protein synthesis and maturation. The loss of such a mechanism could expose shade-adapted algae to full sunlight (Jones \& Hoegh-Guldberg 2001), thus explaining the susceptibility of heavily pigmented corals morphs to thermal bleaching.

Alternatively, chromophore formation associated with elevated levels of folded protein may produce deleteriously high concentrations of hydrogen peroxide, a predicted by-product of oxidation of the chromophore by $\mathrm{O}_{2}$ (Tsien 1998). Hydrogen peroxide is a product and known inhibitor of CuZnSOD (Haberland et al. 1993). Inhibition of this enzyme may lead to a build up of superoxide radicals generated by the thermally damaged photosynthetic apparatus of the resident algae. CuZnSOD is abundant in host tissue (Richier et al. 2003) and therefore could explain the loss of host animal soluble protein in the blue morph of Acropora aspera as a result of oxidative damage (Stryer 1988).

Colonies sampled in the field towards the end of the 2002 bleaching event (Denis 2002) had experienced several heating episodes, with at least one of these episodes as hot as the mean 10:00 $\mathrm{h}$ to 17:00 $\mathrm{h}$ temperature experienced during the heating period of the experiment. Light conditions were also similar for the 7 hot days (cf. experimental $1273 \mu \mathrm{mol}$ quanta $\mathrm{m}^{-2} \mathrm{~s}^{-1}$ and field $1315 \mu \mathrm{mol}$ quanta $\mathrm{m}^{-2} \mathrm{~s}^{-1}$; Fig. 4A,C). Field corals in the week prior to this period of high temperature experienced much greater irradiance than experimental corals (cf. field $1149 \mu \mathrm{mol}$ quanta $\mathrm{m}^{-2} \mathrm{~s}^{-1}$ and experimental $730 \mu \mathrm{mol}$ quanta $\mathrm{m}^{-2} \mathrm{~s}^{-1}$; Fig. 4E). Field corals did not experience a month of low temperature and light levels (as in the experiment) in which to recover (Fig. 4). Blue and light blue colonies collected from the field in March 2002 had reduced symbiont densities in comparison to samples taken prior to the bleaching events. In contrast, the symbiont densities in the cream morph were unchanged (Fig. 7A). This is very similar to the situation observed on experimental Day 7 (d7) where blue and light blue, but not cream, colonies had significantly less symbionts with the heat treatment than in the controls (Fig. 3). The only difference was that cream and light blue morphs in the field were not photo-bleached prior to increases in ambient temperature (Fig. 7).

In terms of symbiont photosynthetic ability, all 3 morphs were equally sensitive at lower temperature, but subtle increases in temperature led to divergent responses (Fig. 5B1-3). A 10:00 h to 17:00 h mean temperature increase of $0.9^{\circ} \mathrm{C}\left(30.0\right.$ to $30.9^{\circ} \mathrm{C}$ ) had no effect on the light blue morph, a minimal effect on photosynthetic efficiency in the cream morph, but a drastic effect on the blue morph both in terms of symbiont 
photosynthetic efficiency and survival (Figs. 4-6). The IPCC projections offer a best-case scenario of a 0.5 to $2.0^{\circ} \mathrm{C}$ increase in sea surface temperatures by 2050 . High branch mortality was observed in June and July 2002 amongst colonies of blue Acropora aspera; unfortunately it was not quantitated. Warmer scenarios (such as Tank 3) are projected to occur some decades from now. It is unlikely that the blue morph of $A$. aspera will develop thermal tolerance to these conditions in this time frame.

This study has shown that host pigments in scleractinian corals shield resident algae from photoinhibition when corals are moved from semi-shade to a day of full sunlight. It has also shown, contrary to predictions, that pigmentation renders at least one colour morph more sensitive to increases in temperature. Currently, we can only speculate on the mechanisms that are behind these results. If mass bleaching events increase at the frequency predicted, colourful corals on the reef may be the early rather than late victim of global warming.

Acknowledgements. I would like to thank my research assistants B. Cameron, W. Garriock and C. Pettigrew; my student, P. Fisher, for sequencing algal ITS regions; my colleagues, Prof. O. Hoegh-Guldberg and Dr R. Jones, for reading and commenting on drafts of this manuscript. We acknowledge a grant to S.D. and O. Hoegh-Guldberg from the Australian Research Council for providing the funds for this project.

\section{LITERATURE CITED}

Anthony K, Hoegh-Guldberg O (2003) Kinetics of photoacclimation in corals. Oecologia 134:23-31

Baird GS, Zacharias DA, Tsien, RY (2000) Biochemistry, mutagenesis, and oligomerization of DsRed, a fluorescent protein from coral. Proc Natl Acad Sci USA 97:11984-11989

Banaszak AT, LaJeunesse TC, Trench RK (2000). The synthesis of mycosporine-like amino acids (MAAs) by cultured, symbiotic dinoflagellates. J Exp Mar Biol Ecol 249: $219-233$

Berner T, Baghdasarian G, Muscatine L (1993) Repopulation of a sea anemone with symbiotic dinoflagellates: analysis by in vivo fluorescence. J Exp Mar Biol Ecol 170:145-58

Bevis BJ, Glick BS (2002) Rapidly maturing variants of the Discosoma red fluorescent protein (DsRed) Nature Biotech. 20:83-87

Brown BE, Howard LS (1985) Assessing the effects of stress on reef corals. Adv Mar Biol 22:1-6

Brown BE, Ambarsari I, Warner ME, Fitt WK, Dunne RP, Gibb SW, Cummings DG (1999) Diurnal changes in photochemical efficiency and xanthophyll concentrations in shallow water reef corals: evidence for photoinhibition and photoprotection. Coral Reefs 18:219-230

Brown BE, Dunne RP, Goodson MS, Douglas AE (2002) Experience shapes the susceptibility of a reef coral to bleaching. Coral Reefs 21:119-126

Bulina ME, Chudakov DM, Mudrik NN, Lukyanov KA (2002) Interconversion of Anthozoa GFP-like fluorescent and non-fluorescent proteins by mutagenesis. BMC Biochem $3: 7$
Coleman AW, Suarez A, Goff LJ (1994) Molecular delineation of species and syngens in volvocacean green algae. (Chlorophyta). J Phycol 30:80-90

Denis C (2002) Reef under threat from 'bleaching' outbreak. Nature 415:947

Dove SG, Takabayashi M, Hoegh-Guldberg O (1995) Isolation and partial characterization of the pink and blue pigments of pocilloporid and acroporid corals. Biol Bull (Woods Hole) 189:288-297

Dove SG, Hoegh-Guldberg O, Ranganathan S (2001a) Major colour patterns of reef-building corals are due to a family of GFP-like proteins. Coral Reefs 19:197-204

Dove SG, Hoegh-Guldberg O, Prescott M, Karan M, Brugliera F, Mason J (2001b) Cell visualising characteristic modifying sequences. World Intellectual Property Organisation PCT/GB02/00928

Dunn SR, Bythell JC, Le Tissier MDA, Burnett WJ, Thomason JC (2002) Programmed cell death and cell necrosis activity during hyperthermic stress induced bleaching of the symbiotic sea anemone Aiptasia sp. J Exp Mar Biol Ecol 272: $29-53$

Falkowski PG, Dubinsky Z (1981) Light-shade adaption of Stylophora pistillata, a hermatypic coral from the Gulf of Eilat. Nature 289:172-174

Franklin LA, Seaton GGR, Lovelock CE, Larkum AWD (1996) Photoinhibition of photosynthesis on a coral reef. Plant Cell Environ 19:825-836

Fitt W, Cook C (2001) Photoacclimation and the effect of the symbiontic environment on the photosynthetic responses of symbiotic dinoflagellates in tropical marine hydroid Myrionema amboinense J Exp Mar Biol Ecol 256:15-31

Gates RD, Baghdasarian G, Muscatine L (1992) Temperature stress causes host cell detachment in symbiotic cnidarians: implications for coral bleaching. Biol Bull (Woods Hole) 182:324-332

Gross LA, Baird GS, Hoffman RC, Baldridge KK, Tsien RY (2000) The structure of the chromophore within DsRed, a red fluorescent protein from coral. Proc Natl Acad Sci USA 97:11990-5

Gurskaya NG, Fradkov AF, Terskikh A, Matz MV, Labas YA, Martynov VI, Yanushevich YG, Lukyanov SA (2001) GFPlike chromoproteins as a source of far-red fluorescent proteins. FEBS Lett 507:16-20

Haberland A, Mader K, Stosser R, Schimke I (1993) Comparison of malondialdehyde and hydrogen peroxide modified CuZnSOD by EPR spectroscopy. Agents Actions 40: 166-70

Hoegh-Guldberg O (1999) Climate change, coral bleaching and the future of the world's coral reefs. Mar Freshwater Res 50:839-866

Iglesias-Prieto R (1997) Temperature-dependent inactivation of Photosystem II in symbiotic dinoflagellates. Proc 8th Int Coral Reef Symp 2:1313-1318

Iglesias-Prieto R, Trench RK (1997) Photoadaption, Photoacclimation and niche diversification in invertibratedinoflagellate symbioses. Proc 8th Int Coral Reef Symp 2: $1319-1324$

Jerlov NG (1976) Marine optics. Elsevier, Amsterdam

Jones RJ, Hoegh-Guldberg O, Larkum AWD, Schrieber U (1998) Temperature induced bleaching of corals begins with impairment of dark metabolism in zooxanthellae. Plant Cell Environ 21:1219-1230

Jones RJ, Hoegh-Guldberg O (2001) Diurnal changes in the photochemical efficiency of the symbiotic dinoflagellates (Dinophyceae) of corals: photoprotection, photoinactivation and the relationship to coral bleaching. Plant Cell Environ 24:89-99 
Jones RJ, Yellowlees D (1997) Regulation and control of intracellular algae (= zooxanthellae) in hard corals. Phil Trans R Soc Lond B 352:457-468

Kawaguti S (1944) On the physiology of reef corals VI. Study on the pigments. Palao Trop Biol Stn Stud 2:617-673

Krause GH, Weis H (1991) Chlorophyll fluorescence: the basics. Plant Mol Biol 42:313-349

Kuhl M, Cohen Y, Dalsgaard T, Jorgensen BB, Revsbech NP (1995) Microenvironment and photosynthesis of zooxanthellae in scleractinian corals studied with microsensors for $\mathrm{O}_{2}, \mathrm{pH}$ and light. Mar Ecol Prog Ser 117:159-172

Labas YA, Gurskaya NG, YanushevichYG, Fradkov AF, Lukyanov KA, Lukyanov SA \& Matz MV (2002) Diversity and evolution of the green fluorescent protein family. Proc Natl Acad Sci USA 99:4256-4261

LaJeunesse TC (2001) Investigating the biodiversity, ecology and phylogeny of endosymbiotic dinoflagellates in the genus Symbiodinium using the ITS region: in search of a species level marker. J Phycol 37:866-880

Leggat W, Buck B, Grice A, Yellowlees D (2003) The impact of bleaching on the metabolic contribution of dinoflagellate symbionts to their giant clam host. Plant Cell Environ 26: 1951-1961

Makino Y, Amada K, Taguchi H, Yoshida M (1997) Chaperonin-mediated folding of green fluorescent protein. J Biol Chem 272:12468-74

Matz MV, Fradkov AF, Labas YA, Savitsky AP, Zaraisky AG, Markelov ML, Lukyanov SA (1999) Fluorescent proteins from non-bioluminescent Anthozoan species. Nature Biotech 17:969-973

Mazel CH, Lesser MP, Gorbunov MW, Barry TM, Farrell JH, Wyman KD, Falkowski PG (2003) Green-fluorescent proteins in Caribbean corals. Limnol Oceanogr 48:402-411

Morin JC, Hastings J (1971) Biochemistry of the bioluminescence of colonial hydroids and other coelenterates. J Cell Physiol 77:313-318

Osmond CB, Anderson JM, Ball MC, Edgerton JJG (1999) Compromising efficiency: the molecular ecology of light resource utilization in terrestrial plants. In: Press MC, Scholes JD, Barker MG (eds) Advances in physiological plant ecology. Blackwell, Oxford, p 1-24

Prescott M, Ling M, Beddoe T, Oakley AJ, Dove S, HoeghGuldberg O, Devenish RJ, Rossjohn J (2003) The 2.2 a crystal structure of a pocilloporin pigment reveals a nonplanar chromophore conformation. Structure 11:275-284

Queitsch C, Sangster TA, Lindquist S (2002) Hsp90 as a capacitor of phenotypic variation. Nature 417:618-624

Richier S, Merle PL, Furla P, Pigozzi D, Sola F, Allemand D (2003) Characterisation of superoxide dismutases in anoxia and hyperoxia-tolerant symbiotic cnidarians. Biochim Biophys Acta 1621:84-91

Rowan R, Knowlton N, Baker A, Jara J (1997) Landscape

Editorial responsibility: Otto Kinne (Editor),

Oldendorf/Luhe, Germany ecology of algal symbionts creates variation in episodes of bleaching. Nature 388:265-269

Salih A, Larkum A, Cox G, Kuhl M, Hoegh-Guldberg O (2000) Fluorescent pigments in corals are photoprotective. Nature 408:850-853

Schreiber U, Endo T, Mi H, Asada K (1995) Quenching analysis of chlorophyll fluorescence by the saturation pulse method: particular aspects relation to the study of eukaryotic algae and cyanobacteria. Plant Cell Physiol 36:873-882

Stimson J, Kinzie RA (1991) The temporal pattern and rate of release of zooxanthellae from the reef coral Pocillopora damicornis (Linnaeus) under nitrogen-enrichment and control conditions. J Exp Mar Biol Ecol 153:63-74

Stryer L (1988) Biochemistry. WH Freeman \& Co, New York

Takabayashi M, Hoegh-Guldberg O (1995) Physiological and ecological differences between pink and brown genotypes of the reef-building coral, Pocillopora damicornis. Mar Biol 123:705-714

Tsien RY (1998) The green fluorescent protein. Annu Rev Biochem 67:509-544

Underwood AJ (1997) Experiments in ecology. Cambridge University Press, Cambridge

van Oppen MJH, McDonald BJ, Willis BL, Miller DJ (2001a) The evolutionary history of the coral genus Acropora (Scleratinia, Cnidaria) based on a mitochondrial and a nuclear marker: reticulation, incomplete lineage sorting or morphological convergence? Mol Biol Evol 18:1315-1329

van Oppen MJH, Palstra FP, Piquet AMT, Miller DJ (2001b) Patterns of coral-dinoflagellate associations in Acropora: significance of local availability and physiology of Symbiodinium strains and host-symbiont selectivity. Proc $\mathrm{R}$ Soc Lond B 268:1759-1767

Veron JEN (2000) Corals of the world. Australian Institute of Marine Sciences, Townsville

Warner ME, Fitt WK, Schmidt GW (1999) Damage to photosystem II in symbiotic dinoflagellates: a determinant of coral bleaching. Proc Natl Acad Sci USA 96:8007-8012

Weissman JS, Rye HS, Fenton WA, Beecham JM, Horwich A.L (1996) Characterization of the active intermediate of a GroEL-GroES-mediated protein folding reaction. Cell 84: 481-90

Whitaker JR, Granum PE (1980) An absolute method for protein determination based on difference in absorbance at 235 and $280 \mathrm{~nm}$. Anal Biochem 109:156-159

Yang F, Moss LG, Phillips GN (1996) The molecular structure of green fluorescent protein. Nat Biotech 14:1246-1251

Zar JH (1999) Biostatistical analysis. Prentice Hall, New Jersey

Zardoya R, Costas E, Lopez-Rodas V, Garrido-Pertierra A, Bautista JM (1995) Revised dinoflagellate phylogeny inferred from molecular analysis of large-subunit ribosomal RNA gene sequences. J Mol Evol 41:637-645

Submitted: July 9, 2003; Accepted: February 3, 2004

Proofs received from author(s): May 12, 2004 